\title{
INTERPRETATION OF THE EPITAPH OF CHANGGUN YELÜ ZHUN OF GREAT LIAO IN KHITAN LARGE SCRIPT*
}

\author{
WU YINGZHE-JIRUHE-PENG DARUHAN \\ University of Inner Mongolia, Hohhot 010021, China \\ e-mail: khitan1922@126.com
}

\begin{abstract}
Khitan Large and Small Scripts modelled on Chinese characters were created to record the Khitan language in the 10th century. In June 1922 the thousand-year-old dust-laden Khitan scripts were rediscovered and brought to light again arousing great interest and hot discussions regarding the research of historical nationalities in the terrirory what is now northern China. Up to now approximately seventy pieces of monuments with Khitan inscriptions have been found, mostly epitaphs and eulogies, with a total of 80,000 words. The Epitaph of Changgun Yelü Zhun of Great Liao 大遼 國常衰耶律凖墓誌銘, carved in Khitan Large Script in Xianyong the fourth year (1068), was found at the town of Beizifu, Aohan Banner Inner Mongolia. With its exquisite carving and intact content, this epitaph can be regarded as one of the extant top quality monuments in Khitan Large Script. It is the first time that the rubbing, the manuscript and the interpretation of this epitaph are presented to the public. This paper compares the graphemes of the Large Script and the Small Script, in order to deduce the unknown from the known. Understanding the nature of the Khitan Large Script and investigating different Khitan materials, we can state that numerous Large Script graphemes matched with the corresponding Small Script graphemes. Based on the research findings of the Khitan Small Script graphemes and the historical records of the Yaonian clan, this paper attempts to reveal the wording habit, the combination rule of the graphemes of the epitaph text and the context of the words, in order to decipher some Large Script graphemes untouched before and to reconstruct or correct the pronunciation of some graphemes of the Large Script.
\end{abstract}

Key words: Khitan Large Script, Khitan Small Script, Epitaph of Yelü Zhun, interpretation.

* This paper is supported by the key programme of Philosophy and Social Science "Collation and Study of Handed-down Documents in Khitan and Jurchen" (14JZD036) of China's Ministry of Education and the project "Interpretation of the Khitan Scripts and Study on the Khitan Vocabulary" (13YJA740059) of the Humanities and Social Science Fund of China's Ministry of Education, and the youth programme of Philosophy and Social Science "Collation and Study of Handed-down Documents in Khitan" (14YJC740034) of China's Ministry of Education, and also one of the research results of the programme "Achievement Transformation of Khitan Scripts Interpretation and Research on Cultural Industry Development of Liao Shang Jing Area” (MW-YB-2015021). 


\section{Research Background}

Khitan scripts, classified into Large and Small Scripts, were modelled on Chinese characters in the 10th century to record the Khitan language. The Large Script, which is a logo-syllabic script, was created by Emperor Taizu Yelü Abaoji with the help of Yelü Tulübu and Yelü Lubugu in the 5th year of Shence of Liao (A.D. 920). The Small Script, created a bit later than the Large Script, is a logo-syllabic and phonemic script created by Yelü Diela, the younger brother of Emperor Taizu, inspired by the spoken and written language of the Uighur. At that time Khitan scripts, mainly used in such areas as stele marking, recording names of towns and villages, poetry writing, book translation, tally carving and diplomatic correspondence, had the status and function of an official language in Liao. During the Liao Dynasty the two kinds of Khitan scripts existed side by side for over 200 years. After the collapse of the Liao Dynasty, the Jurchen, who established the Jin Dynasty, still used Khitan scripts until the 2nd year of Mingchang of Emperor Zhangzong of the Jin Dynasty (A.D. 1211). From creation to abolishment, Khitan scripts were used across the Liao and Jin Dynasties, which lasted roughly for over 270 years. Different scholars share different views on the extinction of Khitan scripts, but the majority believes that by the ascension of the Ming dynasty (1368 A.D.), at the latest, Khitan scripts must have been forgotten. After the Ming and Qing Dynasties Khitan became a dead language that no one spoke and knew. The Khitan documents were also lost and disappeared for the most part, without any paper documents having survived so far, except a manuscript found in Russia in recent years.

Since the early 1920s, Khitan inscription documents have been rediscovered successively from former Khitan hinterland centred on eastern Inner Mongolia and Liaoning Province. Dust-laden Khitan scripts have been brought to light again, which aroused huge interest and heated debates in their research. Up to now 47 inscriptions in Small Script and 18 inscriptions in Large Script and a manuscript have been found. Although these historical documents have not as yet been fully deciphered, their research value in linguistics, history and philosophy should not be underestimated. Specifically, both Khitan and Mongol are descendants of Donghu. With mutually comprehensible languages, Khitan documents can fill in the blanks of Mongol materials before the 13th century. Moreover, Khitan scripts are of great historical and academic value in restoring the history of Liao and Jin. Besides, Khitan characters preserved a large number of Chinese loanwords, such as names of people, places, official titles, titles of nobility 爵號, titles and noble orders 勳號, etc. These loanwords persevered in phonetic forms that reflected the Chinese phonology about a thousand years ago, so they can be helpful in filling the gaps in Chinese phonetic studies. For the abovementioned reasons, the development of Khitan script studies has always been much appreciated by academia throughout the world.

When Khitan studies just started, with scarce unearthed documents and references, the interpretation involved much difficulty. The startup phase, the research of which was mainly based on speculation and on literal meaning, lasted from the 1920s to the 1940s. The Japanese scholar Haneda Tōru (1925, pp. 82-96), Chinese scholars 
Luo Fucheng (1934, pp. 113-121), Wang Jingru (1933, pp. 467-478) and Li Dingkui (1932, pp. 563-572) etc. published papers, interpreting a series of Khitan words.

During the 1950s and 1960s, exploring phonics and formulating pronunciation became the mainstream. Researches on the Small Script were very intensive in different countries. For example, the Japanese scholars Yamaji Hiroaki (1956), Murayama Shichiro (1951, pp. 47-69, 182-185), Osada Natsuki (1951, pp. 44-66) and others made attempts to interpret Khitan scripts from different perspectives. In addition, L. N. Rudov, V. S. Taskin, V. S. Starikov from the former Soviet Union, Louis Hambis from France, Karl Heinrich Menges from Germany, Louis Ligeti and György Kara from Hungary wrote books and set up theories which have greatly promoted the Khitan studies.

In 1970-1980, researchers were oriented to defining pronunciation and meanings. In this period, Khitan studies in China made considerable progress, especially the achievement of a Khitan research group (Chinggeltei, Liu Fengzhu, Chen Naixiong, Yu Baolin and Xing Fuli) can be considered remarkable. The publication of research findings in Research on Khitan Small Script (Chinggeltei-Liu Fengzhu-Chen Naixiong - Yu Baolin-Xing Fuli 1985) represented the highest level of the field both in China and abroad and was highly appreciated in the international academic world. Its epoch-making significance in the history of Khitan studies is undeniable.

Since 1990, with first-hand materials having been unearthed and discovered in succession, the studies on Khitan scripts have flourished and entered a new period of development. Statistics show that about 280 Small Scripts and nearly 2500 words have been interpreted and more than 10 kinds of phonetic and grammar rules have been revealed so far. With the extant findings, the researchers are able to sort out the basic context of materials written in the Small Script and understand such general contents as names of epitaphs, carving year, family backgrounds and life stories of the epitaph owners, etc.

In comparison, studies on the Large Script due to their logographic nature have been lagging behind those on the Small Script. In 2004, Liu Fengzhu and Wang Yunlong (2004, pp. 61-99) published a paper interpreting the Epitaph of Yelü Changyun 耶律昌允墓誌銘 written in the Large Script, presenting a series of fresh interpretation findings. It is noteworthy that the study put forward a new explanation of the nature of the Large Script, assuming that there exist many phonetic components in the Large Script. Follow-up studies showed indeed that there did exist a number of phonetic components. Thus, by the nature of the script, the primary difference between Small and Large Scripts lies in their phonemic degree or the number of phonographic components. This realisation has promoted progress in interpreting the Large Script, and provided very favourable conditions for the comparative study of the Small and the Large Scripts. Statistics show that more than 240 Large Scripts and over 600 words (Liu Fengzhu 2014, pp. 444-448) have been interpreted so far. However, there is still much to be explored concerning the grammar rules.

The present study systematically investigates the newly found Epitaph of Changgun Yelü Zhun of Great Liao 大遼國常衰耶律隼墓誌銘 in Khitan Large Script, making a full disclosure of the rubbing, the full text and the interpretation of the 
epitaph for the first time, and simultaneously interprets some monuments written in Khitan Large Script that are yet to be tackled or interpreted on the basis of the previous studies. While the authors put forward their own views, they await new ideas and pieces of advice from the scholars in the field.

\section{Interpretation of the Epitaph of Changgun Yelü Zhun of Great Liao in Khitan Large Script}

The Epitaph of Changgun Yelü Zhun of Great Liao 大遼國常衰耶律凖墓誌銘 (hereafter referred to as Yelü Zhun 耶律凖) in Khitan Large Script was recently found near the town of Beizifu, Aohan Banner Inner Mongolia. The epitaph consists of a cover stone and a base stone. The cover stone is in the shape of Lu-roof, with a side length of $72 \mathrm{~cm}$, thickness of $7 \mathrm{~cm}$ and the side length of the central facet is $30 \mathrm{~cm}$. By the two-lined flowers decoration, the front of the cover stone was intaglioed as character 井 and divided into nine parts. Eight seal characters “大遼國常衰耶律凖” (Great Liao State Chuangun Yelü Zhun) were carved on the central facet in 3 lines. On the corners of every slope, peony decorations were incised and three human figures with hand board in hand and official hat on head were incised between every two peonies, which were encircled by auspicious clouds and thunder decorations. The beautifully designed and well-portrayed ornamentations reveal the prominent position of the epitaph owner when he was alive.

The base stone is also in the shape of square, with a side length of $72 \mathrm{~cm}$ and thickness of $10 \mathrm{~cm}$. The front side was carved vertically from right to left with 1433 Khitan graphemes in the Large Script, divided into 36 lines. Except for four indecipherable, diffuse and unclear characters, the vast majority of the remaining characters are preserved intact. The epitaph text was encircled by the two-lined clouds and thunder decoration, and the base stone was exquisite with auspicious clouds decorations.

\section{1. 地印 Tigin (official title)}

According to the writing style of the Khitan epitaph, the name of the epitaph and the compiler of the epitaph text will be introduced in the first line, in which the following words appear after two blank spaces followed the expression of 未州行比兴 which mean 'with preface'. The blank space here suggests that the contents before and after are different.

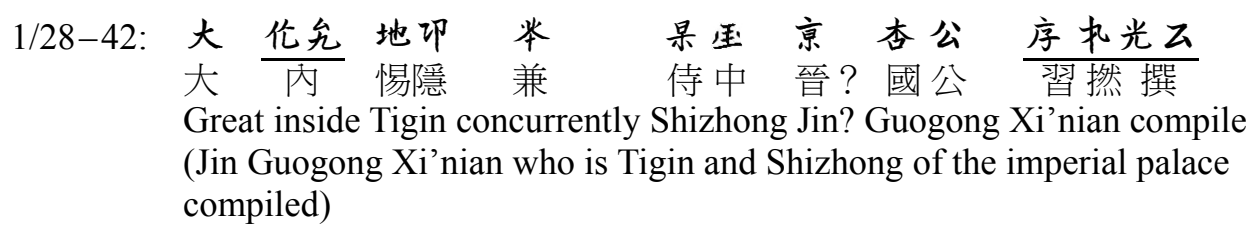


The words with the meanings of 'inside', 'concurrently', 'Shizhong', 'Guogong' and 'compile' have already been interpreted, so we can deduce that 大伦允 地印 would be “Tigin of the imperial palace" and 序 f would be a personal name “Xi'nian", but whether the word 京 means “Jin" of “Jin Guogong” is not certain, which needs further examination.

It was clarified that the Khitan graphemes 伦允 are the transliteration of the Chinese character 內 'nei', pronounced as 'nui' in Khitan. The Khitan grapheme 大 before 伦允 is obviously the transliteration of the Chinese character 大 'da', pronounced as 'dai', so 大伦允 will be the transliteration of 大內 (imperial palace). In Khitan Small Script 今キ头公尒王炎雨 mean “Tigin of the imperial palace” (Line 14 of Zongjiao 宗教) which indicates that the Khitan Large Script graphemes 地印 may also be the transliteration of 惕隱. From the corresponding relation between the Large and the Small Script, the last grapheme 雨 of 王炎雨 corresponds to 印 in the Khitan Large Script, both of which are used as genitive affixes, and pronounced as 'in', therefore, it can be presumed that 王炎 corresponds to 地. It is known that 王炎 is read as 'ti', so 地 will also be read as 'ti'. 王炎雨 in Khitan Small Script is always written as 王会雨 (Line 8 of Yelü $N u$ 耶律奴), its pronunciations can be reconstructed as 'ti-i-in' and 'ti-go-in' according to previous studies. The second graphemes of these two blocks are 炎 ' $i$ ' and 㕕 'gə' respectively. These different transliterations reflect that a long vowel was formed in Khitan (Wu Yingzhe 2007a, p. 103). A similar phenomenon can also be seen in other words, for example, in the word $\boldsymbol{~}$ 为共 ' $\int(a)$-a-ri' is sometimes written as 王去 ' $\int(a)$-ya-ri'. According to previous studies homographs in the Large Script and in Chinese can be connected to their identical or similar pronunciations, for example, 太 'tai' and 太 'thai', 公 'kuy' and 公 'kuy', 主 ' $\mathrm{giu}$ ' and 主 'tciu'. This fact supports the reconstructed pronunciations of 地 as 'ti' and 大 as 'dai'.

The Tigin of the imperial palace is the official title of the compiler 㢁 れ. It is known that 序 corresponds to the Small Script 伞雨 'sin', while f to 当 'en', that is to say, 序 丸 corresponds to 全雨当, pronounced as 'sinen', which exactly equals to the personal name 習撚in Chinese. A person named 全雨与 whose other name is 永 (su) is the master in Khitan language in the Liao Dynasty. Several epitaphs like Tuguci 圖古辭 were compiled by him. Some scholars proposed that 全雨骂永 is the Khitan name of Yelü Liang (Yelü Bai) who is recorded in the History of Liao ([Yuan] Tuotuo et al. 1974, p. 1398). From the record, it can be clearly observed that Yelü Liang (Yelü Bai) had taken up the position of Tigin, which is the proof of 地印 as Tigin. In addition, there is a clear record in the Khitan Small Script that 企雨当承 once had been Tigin, for example, 全雨当承王会雨网丸 mean 'Xi'nian Su Tigin compiled' (In Line 1 of Tuguci 圖古辭).

\section{2. 求掉谈血沓身州芥王本 Telin Khaan of Six Tribes}

In Line 7 there is a record about the epitaph owner's grandaunt (the wife of the younger brother of the epitaph owner's grandfather) 芙交仍 'a madam'. Then follows 
a record about the epitaph owner's wife who is the descendant of Telin Khaan of Xi Six Tribes (六部奚 $\mathrm{Liu} \mathrm{Bu} \mathrm{Xi):}$

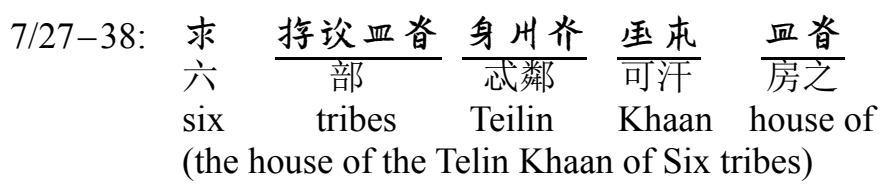

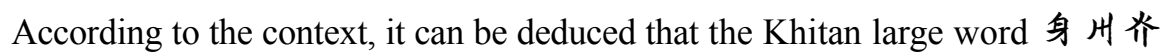
might be of compound characters. It has already been established that the grapheme 身 means 'this' or 'that', its corresponding grapheme in the Small Script is $\square$, and the corresponding graphemes of $⿻$ 州 in the Small Script are 乐 and 伏. Therefore, the graphemes 身卅芥 should correspond to $\square$ 水伏 in the Small Script. The block 口伙伏 has never appeared in the extant materials, but the block $\square$ 比伏 with similar pronunciation occurred frequently. $\square$ 比伏 is recognised as the transliteration of 'Telin', the name of Xi Khaan, pronounced as *'təlin' (Aisin Gioro - Yoshimoto Michimasa 2011, p. 7) which indicates that the second grapheme tt includes a consonant ' 1 '. The second grapheme of the word 身州芥is also read as ' 1 ', so 身州芥 may correspond to 口比伏 in pronunciation. Another example which supports this corresponding relation is the word 身 月芥 in Line 4 of Liuyin 留隱, the second script of which 月 is with the same pronunciation as 圷. The reason for that is that the expression of 'with' of 'with preface' is written as 凡兴月 in Large Script and 杂公地 in Small Script, so 马 corresponds to 比. Taking an overall view of the materials in Khitan Small Script, it is observed that 你 and 比 are used interchangeably, for example, 罗比态万 in Line

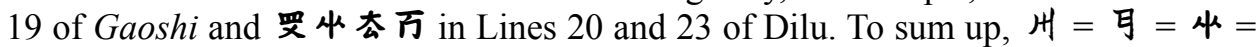
地, then 身州齐二身可齐 $=$ 口比伏 which is the personal name Telin. Both the Khitan Large Script 月 and the Khitan Small Script tt are read as 'li'.

In the example above, the two graphemes 王本 together with 身州齐 and 血苗 may mean 'Telin $\square \square$ house of'. According to the materials in Khitan Small Script, it is very common to see that 'the house of Telin Khaan' is recorded as 口比伏 來正夹曲公本 in Line $52 X u$ Wang 許王, and 'the house of Boluen Khaan' is 外及伏巫亚夹曲会机 in Line 45 of Zhen'guo 鎮國. Therefore, the two graphemes 王本 may mean 'Khaan', which appeared in 年本界寺 'at Khaan's period' in Line 5 of Yelü Qi 耶律祺. 來芷夹不雨 (in Line 5 of Yelü Xiangwen 耶律詳穩), in materials in Khitan Small Script they also mean 'at Khaan's period' with the similar meaning to 王本男寺. 皿王 in Line 22 of Yongning Jun 永寧郡 meant 'house Khaan' indicating 'Emperor', expressed in a way specific to the Khitan language. There is a record with similar meaning in Khitan Small Script, for example, 曲公來 in Line 17 of Yelü Jue 耶律玦. From the correspondence it is certain that 年本 means 'of Khaan'. The corresponding relation in pronunciation between 王本 and 來亚夹is: 王 $=$ 巫, read as ' $\mathrm{xa}$ ', and 本 = 主夹, read as 'yan'.

The script 求 in 求将竕血苗 appeared before 'of Telin Khaan's house' means 'six' which has already been interpreted. The similar record as 承将讼血苗 occurred in Line 1 of Xiao Xiaozhong 蕭孝忠. From the record in Khitan Small Script, the latter 将讼血苗 may mean 'of tribe'. The reason is: 灰伏井负本口地伏 


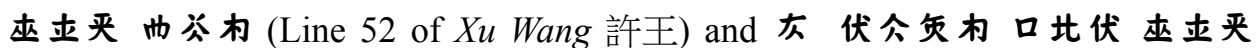
曲公术 (Line 10 of Yelü Taishi 耶律太師), in which the second graphemes of 伏开矢术 and 伏今矢本, although different but have the same pronunciation and meaning 'of house of Telin Khaan of Six Tribes' (Aisin Gioro-Yoshimoto Michimasa 2011, p. 7). Therefore, the Khitan Large Script graphemes 求掉讼血苗 obviously correspond to the Khitan Small Script graphemes 灰伏开矢朴 (伏今矢本) which mean 'of Six Tribes'. On the basis of the interpreted graphemes in Khitan Small Script, the pronunciation of the unknown graphemes in Large Script can be deduced: 掉败

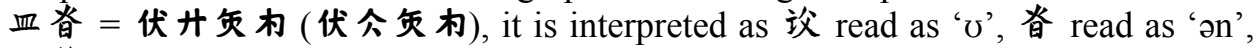
so 掉 $=$ 伏, read as ' $n$ ', 血 $=$ 负, read as 'li'.

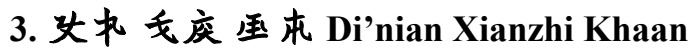

The epitaph owner's name 度 and the courtesy name 徒果芥 appear in the second line of the epitaph. According to the records on the cover stone and in the History of Liao, they are tentatively reconstructed as 'Zhun'隼 and 'Lianning'連寧 (?), as follows:

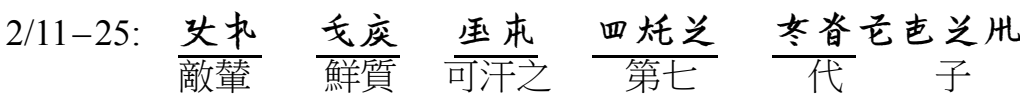 \\ Di'nian Xianzhi Khaan of the seventh generation son \\ (the seventh generation son of Di'nian Xianzhi Khaan)}

Liu Pujiang has proved that 火丸 means 'Di'nian' (Liu Pujiang 2011, p. 286), and 王本 means 'Khaan' (as discussed above). 炎囬 and 代 have already been interpreted as 'generation' and 'son'. According to the materials in Khitan Small Script, the graphemes 丧庆 between 'Di'nian' and 'Khaan' can be deduced as 'Xianzhi'. The corresponding records in Khitan Small Script appeared in Line 7 of Yelü Jue

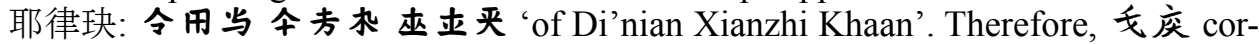

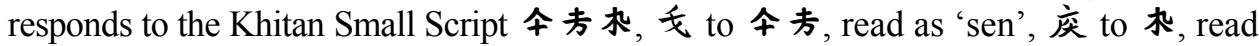
as ' $\mathrm{f}$ '. It means that the pronunciation of the Khitan Large Script 扊 and the Khitan Small Script 机 correspond to each other. See, for example, 早勾兰正扊 in Line 7 of the present epitaph, in which the former three characters mean 'royal uncle' (國舅). The author believes that the latter two characters mean 'Yilibi' (official title). The Large Script $\mathbb{P}$ corresponds to the Small Script graphemes 用丹, read as 'irb ilb'. There are records similar to 力羊出公用丹机 'royal uncle Yilibi' in Line 11 of Gaoshi 高十. The expression of the officer of penalty 'Yilibi' previously appeared as $\mathbb{P} \geq$ and 用 4 . The differences between 疋疾 and 正工, 用出 and 用舟标, are as yet unexplainable, and the question needs further study.

The sequence 四灹兰 means 'the seventh', which will be discussed in detail later in the paper. The meaning of 声兰is unknown. 


\section{4. 州灷俣天及 Chounü San Shizhu}

Before introducing the epitaph owner's experience, a Khitan epitaph always mentions the historical activities of the epitaph owner's ancestors. The epitaph owner is the descendant of Xianzhi Khaan. The records of the next two generations of Xianzhi Khaan have been omitted, while the records are from the great-grandson of Xianzhi Khaan, who is the epitaph owner's great-grandfather, to the epitaph owner himself, Yelü Zhun and his heirs. The record about his great-grandfather is as follows:

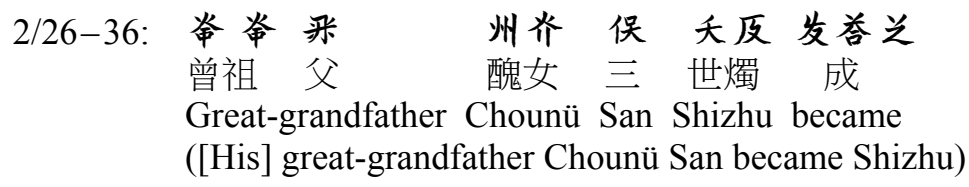

The graphemes 炎: 来 (Line 2 of Xiao Paolu 蕭袍魯) are interpreted as meaning 'great-grandfather', so the sequence 炎㶢采 might have the same meaning, which shows that the grapheme $\mathbf{i}$ in Khitan Large Script may indicate repetition, just as the grapheme : in Khitan Small Script. The word 发券之 'take the position, become' and the remaining graphemes 州灷俣天及can render the name and the official title of his great-grandfather. It has been interpreted by Liu Fengzhu that 俣 is the Chinese loanword 三 san. Therefore, it can be deduced that 州芥俣 天及 correspond to 坫优 羊为乃文头了 in Line 4 of Yelü Jue 耶律玦. The first two characters 州芥 would be a part of a personal name, which can be transliterated as Chounü referring to the person's name 䓅伏 え炎 'Chounü Ge' in Line 15 of Zhixian 智先. Therefore, 州灷 俣 can be interpreted as 'Chounü San'. According to the pronunciation of the grapheme 55 in Khitan Small Script, the pronunciation of the Khitan Large Script 州 can be reconstructed as 'ts' $u \sim \mathfrak{t}^{\prime}$ ' $u$ '.

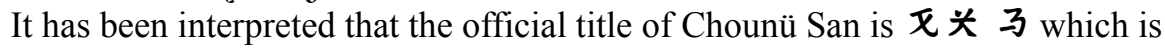
the transliteration of the word 世燭 Shizhu (Aisin Gioro-Yoshimoto Michimasa 2012, p. 86), so in the corresponding Khitan Large Script 夭 及 must be the transliteration of 世燭 Shizhu. The proof of the Khitan Large Script grapheme 夭 read as ' 'i' appeared in Line 15 Xiao Xiaozhong 蕭孝忠, that is, 夭玨, which has been interpreted as the personal name 石婆 Shipo (Aisin Gioro 2009, p. 283). This is certain, because there is historical evidence about its pronunciation in Chinese materials. As for the pronunciation of the grapheme 及 in the Large Script, although there is no corresponding Chinese evidence, we can read it as 'd $3 u$ ' referring to the Small Script 了.

\section{5. 天芥四灹兰 Heshuyin Duoluwo (the seventh)}

The following part of the epitaph is about the great-grandfather Shizhu Chounü San's heir, that is, the introduction of the grandfather of Yelü Zhun:

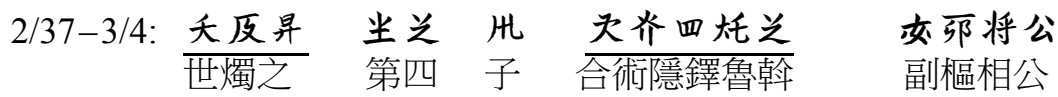


Shizhu's the fourth son Heshuyin Duoluwo Fu Shu Xianggong (The fourth son of Shizhu who named Heshuyin Duoluwo is Fu Shu Xianggong [official title])

The already interpreted graphemes are translated as follows: 'Shizhu's', 'the fourth son' and 'Fu Shu Xianggong'. According to the context, the remaining five graphemes 天乔四灹之 in the middle of the line must render the name of Yelü Zhun's grandfather whose related information appeared in Line 4 Yelü Jue 耶律玦 in Khitan

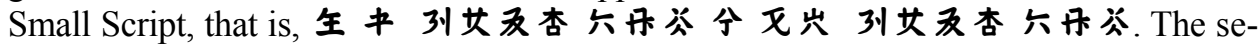
quence between 全 $\neq$ 'grandfather' and 分 岀 'Fu Shu' is obviously a personal name (Aisin Gioro-Yoshimoto Michimasa 2012, p. 109). According to previous studies, 六资 'the seventh' cannot be the attribute of the following 分灭岀 'Fu Shu', because there existed no such expression as 'the seventh Fu Shu'. Since 'the seventh', both in Large and Small Scripts, appeared in the context of 'name', it indicates that they are neither miscarvings, nor the expressions of the ordinal number. Therefore, the ordinal number stands here as a personal name. It is thought-provoking whether this name suggests the person's seniority among brothers and sisters or has some other meanings. It is not surprising that an ordinal number is used as a personal name, see for example, the person's name 杂羅阿夕 'Dolo'adai' (Hitoshi Kuribayashi-Choijinjab 2001, p. 386) in The Secret History of the Mongols meaning 'the seventh'. However, it is an important clue for us to reconstruct the pronunciation of the unknown graphemes of the Large Script. Through the corresponding relation between the Large Scripts 天乔 and the Small Scripts 列共及杏, it can be deduced that the pronunciation of equals to 列共, read as 'h-atfu'. Through the corresponding relation between 四灹关 and 六公, 四 will correspond to the Small Script 六, read as ' $\mathrm{t}$ ', 杔 to the Small Script \#, read as 'lu'. The corresponding relation of 四杔兰 and 六丹资 and the meaning 'the seventh' are important to confirm the generation of Yelü Zhun. This name was reconstructed as 'Heshuyin' by other scholars, which can be regarded as a reference (Aisin Gioro-Yoshimoto Michimasa 2012, p. 109). It has been mentioned that in the part above 四灹兰冬䍐 in Line 2 of this epitaph may mean 'of the seventh generation', so it can be known that Yelü Zhun is the seventh generation heir of Yaonian Xianzhi Khaan. However, in Line 7 of Yelü Jue 耶律玦, Yelü Jue is said to be the eighth generation heir of the Yaonian Xianzhi Khaan. According to our investigation, it does not mean that Zhun is senior to Jue in generation, because the grandfather of both of them is Heshuyin Duoluwo (天乔・四灹兰/列共及杏一六公). They are of the same generation. This difference is due to the different counting of seniority, that is, whether it counts Xianzhi Khaan the first ancestor or not. (For details, see Appendix I: Yelü Zhun Family Genealogical Table.)

\section{6. 承此任石古 four boys}

From Line 3, a section begins that introduces the second son of Heshuyin Duoluwo, 单芥充㐬将号 'General Xiyin - Gaoliu' and his wife 均來交仍 'Madam', the parents of Yelü Zhun who were conferred a posthumous title as 'Shizhong' and ' $\square$ 
Guo Furen'(Madam of $\square$ Guo). There are no more introductions of Xiyin $\bullet$ Gaoliu's elder brother Liuyin - Pusa'nu recorded in Yelü Jue 耶律玦 as 伙丙伏 分全为 公及 who is Yelü Zhun's uncle and Yelü Jue's father. It can be confirmed that Zhun and Jue are cousins. The following part is the introduction of Zhun's brothers and sisters:

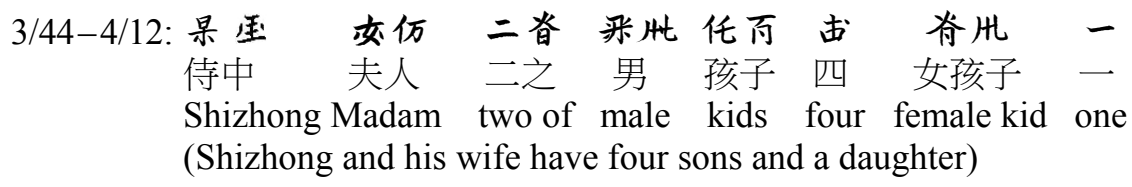

It is interpreted that the former six graphemes mean 'Shizhong Madam two of' (Shizhong and his wife's), then the following 承 means 'male', 任有 'kids' and 年 代 - 'girl one' (a daughter). We think that the eighth grapheme 代, together with 承 mean 'males' (the plural form of adjective 'male'), they correspond to $₹$ 爸 in Small Script. The reason is that 'at north' is written as 空 in Small Script while 圠此 in Large Script, which indicates that 爸 and 此 have the same pronunciation and meaning. Small Script 爷 is with both the grammatical function of dative case and plural suffix, so it is deduced that 此 and 价 have the same meaning and the same grammatical function of plural number. Thus 承什任百㤙 would be interpreted as 'males kids four' (four male kids, four sons), whose corresponding Small Script graphemes are ₹爸丹列出 飞 (Line 14 Yongqing 永清). That is to say, 古 equals to 宅, which means masculine 'four', and read as 'tur' or 'turun'. This is an interesting finding. It is known that cardinal numerals in Khitan Small Script have both masculine and feminine forms:

\begin{tabular}{|c|c|c|c|c|c|c|c|c|c|c|}
\hline Gender & one & two & three & four & five & six & seven & eight & nine & ten \\
\hline Male & モ & 圣 & 包 & 它 & 戈 & 灰 & 居 & 至 & 忝 & 分 \\
\hline Male and female & 乇 & 조 & 包 & 乇 & 戈 & 灰 & 尼 & 垔 & 忝 & 分 \\
\hline
\end{tabular}

There are many cases in Khitan showing that female numerals may also refer to a male, while male numerals never have the function of referring to a female. Hence one can conclude that the gender category in the Khitan language is based on the opposition between 'male' and 'male and female'. Due to the interpretation level, this kind of grammatical phenomenon has not yet been pointed out in materials in

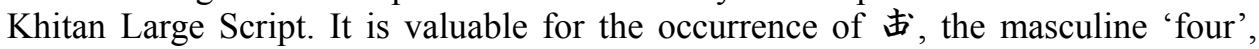
which offers a new content to the study of gender category in Khitan. The Large Script 由 means 'four', and the following part is just about the four sons (male kids), which may indicate that there are also two groups of numerals referring to male and female just like in the Small Script. According to previous research, both characters 内 and 三 in the Khitan Large Script mean 'three', but in different forms, which may be the reflection of the 'male' and 'male and female' opposition. 


\section{7. 皿把不 to inherit the ancestral temple}

In Lines 4 and 5 the epitaph owner's brothers and sisters are introduced: Zhun became the heir to the house of his granduncle and grandaunt.

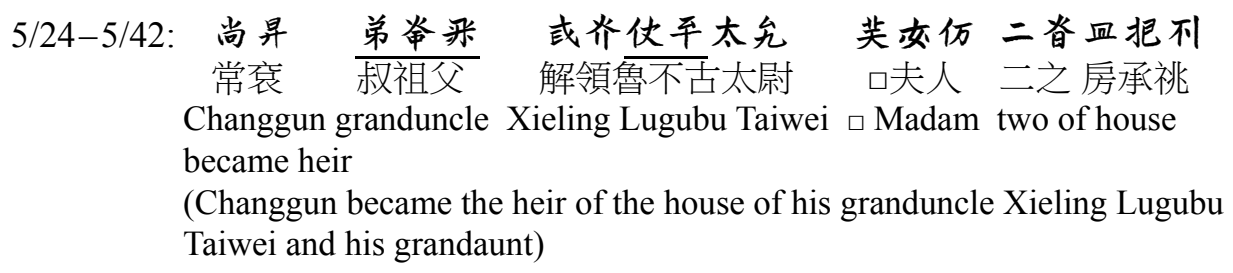

It has been interpreted that the first 16 graphemes mean 'Changgun granduncle Xieling Lugubu Taiwei Madam two of'. From among the following three characters 皿把不, 血 means house ('Fang') corresponding to $\boldsymbol{~}$ 公 in the Small Script, and 不 read as ' $i$ ' corresponding to Small Script grapheme 大, while the pronunciation and meaning of 把 are unknown. We think that 把不 is a word which means 'to inherit' 承祧. We base our opinion on Liu Fengzhu's (Liu Fengzhu-Tang Cailan-Qinggele 2009 , p. 375) interpretation of the block in Small Script 西坐炎资 as meaning 'to in-

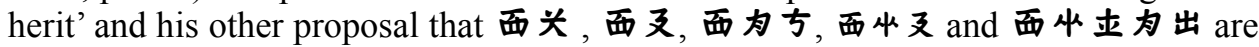
all with the meaning of 'to inherit' (Liu Fengzhu 2014, p. 474). The graphemes $\mathrm{W}$ 公 面头 in the Small Script have the same meaning ('house to inherit' 房承祧) as 皿 把不. In addition, we think that the Small Script graphemes 曲公面为 of Xiao Chala 蕭查剌 correspond to the Large Script graphemes 皿把云 in Line 10 of Yongning Jun 永寧郡, both of them meaning 'to inherit the house' (Fang Chengtiao). From the above analysis, it becomes clear that 把 in Large Script corresponds to 而 in the Small Script, the pronunciation of which is unknown. The whole question requires further examination.

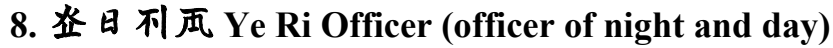

From Line 6 of the epitaph, a man and two women and their relatives are introduced. According to the related information, they should be the children of the epitaph owner.
6/9-21:
负兰帅亚夭本
将虽䀆日不夙兄
將軍夜日之官成?
born son ㅁ General Ye Ri of officer became?
(The son [she] born $\square \square \square$ General became the Ye Ri officer)

The first eight graphemes mean 'born son $\square \square \square$ General'. The other five graphemes mean the official position of someone. The graphemes 日不凩 mean 'Ri officer' (officer of the day), corresponding to 㕕, 杖, 去 in the Khitan Small Script. The meaning of the grapheme 䀆 before 日不凩 cannot be determined; judging by its usage, it cannot be a suffix to the preceding graphemes 将品. The Small Script sequence 全杏天头穴 'Ye Ri officer' is a frequently attested name of an official position, so 
here the character 䍐 before the 'Ri officer' may mean 'Ye', which would correspond to 全杏, read as 'sun suni' in the Small Script. Then the last grapheme 兄 is a verb which may mean 'to become'.

\section{9.未手 after, later on 近忚 relatives}

After introducing the epitaph owner's children in Line 6, in the following part, the 'home tent', i.e. the family home 房帳 (Fangzhang) of the epitaph owner's wife is introduced. In Line 8, there are six graphemes 早幻未手近忚. The grapheme 早 which appears in the word 早勾之 'royal uncle' corresponds to the Small Script 力, read as 'na'. 乣 'die young' corresponds to the Small Script 丙, read as 'iu' which has been interpreted already. The Small Script graphemes 力丙 corresponded to 早幻 appeared twice, however, its meaning was uncertain. From the similar form of the Large Script 早 and the Chinese character 早, it can be deduced that both 早幻 and 力丙 may mean 'die young'.

The next two graphemes 未手 equal to 圠为夹, which may mean 'after'. The Large Script 未 corresponds to the Small Script 圠. The Large Script 平 corresponds to the Small Script 为夹 used to transliterate the Chinese character 安 of 武安州 (臷手人 'Wu Anzhou') in line 9 of Tulibu 突裡不, read as 'an' (Liu Fengzhu 2014, p. 534). It may be tenable to interpret 圠为夹 as 'after'. If the Large Script 未平 is in-

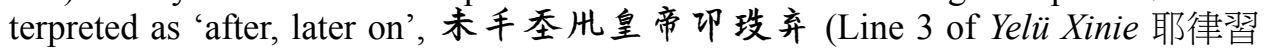
涅) will be interpreted as 'later on, at the time of the son of the heaven, emperor', which sounds clear and coherent.

The last two graphemes 近 忚 may mean 'relatives'. The former 近, which has a similar form to the Chinese character 近, may mean 'be intimate to'. The latter 此, which is the variant of 州, corresponds to the Small Script 爸, read as ' $t$ ', which in turn is an adjectival suffix. The Khitan small graphemes 叉及矢公企爸办去平㕕万 (Line 31 of Wumo 兀沒) were translated as 'Emperor has no relatives' 皇天親無, in which 公企爸本 means 'relatives' (Ji Shi 2012, p. 401). Therefore, 近忚 may be interpreted as 'relatives' and correspond to the Small Script 公企爸. The Large Script grapheme 近 corresponds to 公企 in the Small Script, read as 'nam'.

\section{0. 允夷开寺乃兰 to confer the title of governor (Zhishi), 圣云索 Tianyun Army (Tianyun Jun)}

From Line 8 of the epitaph, the epitaph owner Yelü Zhun's experiences are introduced. Due to the limited interpretation level of the Khitan Large Script, his complete life story cannot be sorted out yet. The official titles appeared in the epitaph, such as 'Assistant Army-commanding Superintendent of $\square$ Capital' (口京之統軍之副使 $\square$ Jing zhi Tongjun zhi Fushi), ‘Chief Military Inspector' (統軍之都監 Tongjun zhi Dujian), 'Great General' (大將軍 Da Jiangjun) and 'Vice Commander of Central Capital' (中 京同知 Zhong Jing Tongzhi), reflect his prominent social status. In addition, accord- 
ing to those disconnected interpretations, we can deduce the pronunciation and meaning of several words. For example:

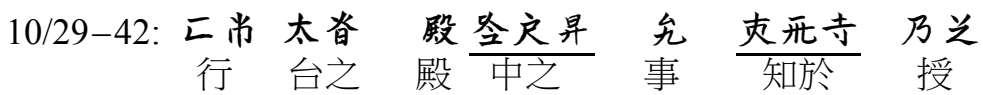

$$
\begin{aligned}
& \text { Hang tai of Dianzhong of matter manage to confer } \\
& \text { (to confer [him] Zhishi [manager of matters] of Dianzhong of Hangtai) }
\end{aligned}
$$

The first two graphemes こ并 appeared in Line 2 of Changyun 昌允, which are recorded as 上事 in some copies, interpreted as 'Hang' 行. From this epitaph, the form of the former character should be $匚$ but not $上$. The following 'Tai of, Dianzhong of, Shi (matter)' have already been interpreted. The next grapheme 贳 is frequently used, before which 允 'matter' or 允弟来 'matter at' always occurs, and after which the suffix 兰 (corresponds to the Small Script 公) or 开寺 (corresponds to the Small Script 㜾矢) etc. always occurs. The combination feature and the specific context of the Large Script 夷 are similar to the Small Script 屋公 and 屋多㜾矢, the first character 㞔 also being frequently used and always combined with 及肠矢 which means 'manage'. 开 corresponds to 及㜾, read as 'ud'.

The last two graphemes 乃兰 should be a verb, in which 乃 may correspond to the Small Script 及全 or 及子 and 兰 to 公. Therefore, 乃关 may mean 'to confer'.

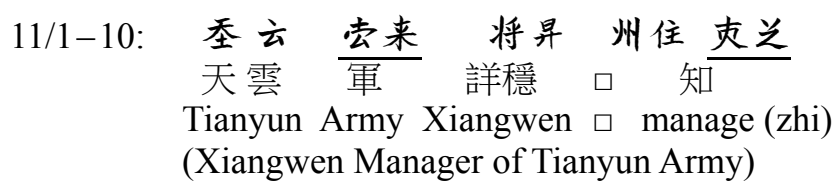

It has been interpreted that 禾 means 'heaven' and 云 means 'cloud'. The grapheme 索 appeared in 索消庆 of Line 14 of the Epitaph of the Great Prince of the North (Beidawang Muzhi 北大王墓誌) which is interpreted as 'governor command' (Dutong) and corresponds to the Small Script 而弱重全. We suppose that the literal meaning of 索冞在本 is 'army command' (Liu Fengzhu 2014, p. 519). The Large Script 索 corresponds to the Small Script 而, while 来 to 玄. Therefore, the Large Script graphemes 索来 correspond to 而交 'army', which is recorded as 炒伍尔 'Chaowuer' in the Guo Yu Jie (Interpretation of the National Language) History of Liao. The Khitan Small Script graphemes 而交 have been interpreted by Ji Shi (Ji Shi 1996). The graphemes 将畀 have been interpreted as 'Xiangwen' (official title). The next graphemes are 州住, of which 州 corresponds to the Small Script 55 and 住 occurred in the word 左住 meaning 'of Yuyue' (Line 1 of Yelü Qi 耶律祺) and corresponds to the Small Script 公. So 州住 corresponds to 劢公. There is no final conclusion about the meaning of the Small Script 坫公 after long-time discussions. Referring to the record of 'Tianyu Jun Xiangwen Si' (Department of Xiangwen of Tianyun Army) in the History of Liao, 坫公 can be seen as 司 Si? (Department, office) ([Yuan] Tuotuo et al. 1974, p. 740). According to the analysis above, it is known that the last two graphemes 灰兰 correspond to 屋炎. Therefore, 禾云索来将开州住灰 之 can be interpreted as 'Tianyun Jun Xiangwen Si? Zhi' (the governor of the Department of Xiangwen of Tianyun Army), while the Small Script graphemes 䏌午 
而交全各必。夾。屋及的矢.及态 (Line 7 of Zhenguo 鎮國) mean 'to confer (somebody) Tianyun Jun Xiangwen Zhishi (Xiangwen Governor of Tianwen Army)', which may relate to the Large Script graphemes above.

\section{1. 㤏 to confer (to supplement), 是合方 (?)}

From the interpretation of Lines 11-14 we have learnt that the epitaph owner had held the posts of 'Inspector' 觀察 (Guancha), 'Dushi' 度使 ,'Superintendent of Five Yuan’五院都監 (Wuyuan Dujian), 'Inspecting grand tutor’ 檢校太傅 (Jianjiao Taifu), ‘Feudal provincial governor' 諸州刺史 (Zhuzhou Cishi), 'Provincial censor' 禦史 (Yushi), 'Superintendent' 都監觀察使 (Dujian Guancha Shi), 'Military commissioner of Tongzhou' 同州之節度使 (Tongzhou Jiedushi). The graphemes 兴人昇允夷工 mean 'the governor of Fuzhou' 鄜州之事知 (Fuzhou zhi Zhishi) followed by 卷, a verb the meaning of which may relate to 'to confer or to supplement (an official title)'. 夾舍仁午寺卷 in Lines 17-18 can be interpreted as ' $\square \square$ personal title to confer (supplement)' (to confer or supplement a title to somebody). From the materials in Large and Small Scripts 卷 may mean 'to confer, to supplement' and corresponds to the Small Script graphemes 及太 or 仍兴, for example,

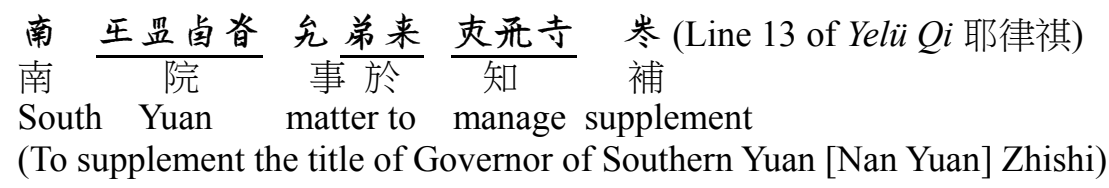

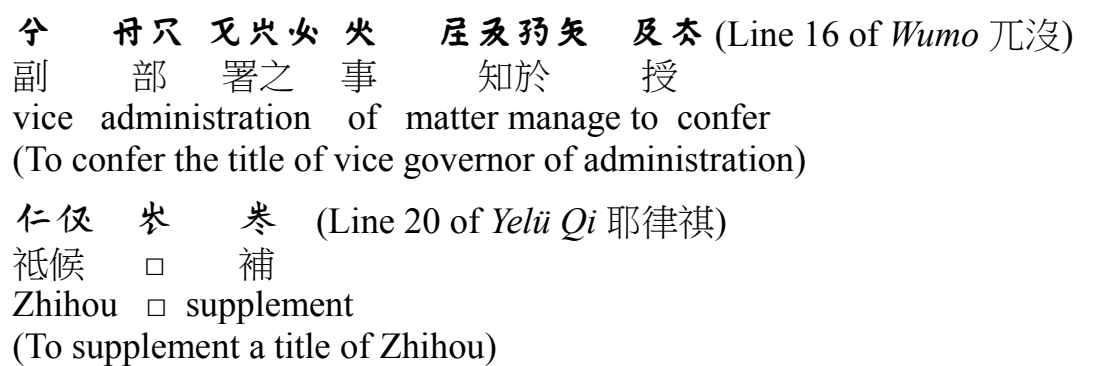
几止 八㜾矢仍头 (Line 11 of Yelü Dilie 耶律迪烈)
祇候口補
Zhihou $\square$ supplement
(To supplement a title of Zhihou)

The following 'Left Military General' (Zuo Wuwei Shang Jiangjun), 'became Changgun in summer of Xianyong 1st year', 'Changgun is the eldest son of House of the Eldest Uncle (孟父房)' have been interpreted already. It is known that the graphemes 誉 and 方 in the word 足券方 in Line 19 correspond to the Small Script graphemes 㕕(厺) and 火 respectively, so 是券方 correspond to 火全㕕火 (also written as 火全厺火). The reason for that, as can be seen from the extant materials, is that the char-

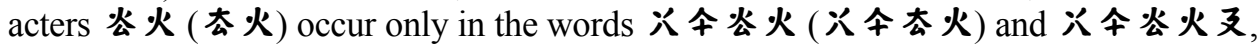


and never appear in any other compound characters. Therefore, the roots of the words 足 and $\boldsymbol{X}$ 全 may have a similar meaning. On the basis of the pronunciation of the Small Script graphemes $火$ ' $\mathrm{x} / \mathrm{k}$ ' and 全 ' $\mathrm{s}$ ', the Large Script 足 could be read as 'xis/kis'. The Large Script graphemes 是券交 and 是券传关 are cognate words

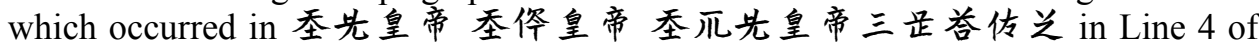
Yelü Xi'nie 耶律習涅, and were interpreted as 'Tianshou Emperor, Tianshun Emperor, Tianzan Emperor three'. The meaning of the last four graphemes 是券传关 have not been reasonably explained, but they may correspond to the Small Script 수수소.

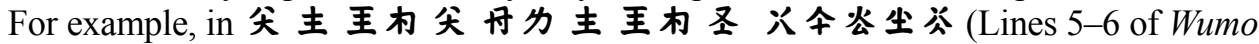
兀沒), which was interpreted as 'Tian Huangdi Tianzi Huangdi two' (Heaven Em-

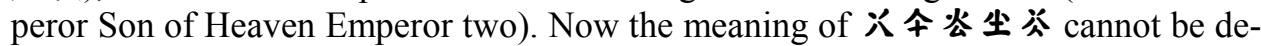
termined, but from its corresponding relations with 是兴传之, it can be deduced that the Large Script 传 equals to the Small Script 尘, read as ' $t$ ' (Wu Yingzhe 2007a, p. 95).

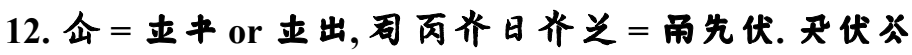

It is recorded in Line 22 of the epitaph that the epitaph owner died of illness, that is, 禾元三来十月十三日寺......并司关荒五拎二 'On October 13th Xianyong 3rd year (1067) ... died of illness at the age of 62', of which 荒 is a newly found Large Script grapheme with the meaning of 'to die, decease'. In the following part, the epitaph owner's wife and son are mentioned who had the epitaph make for him.

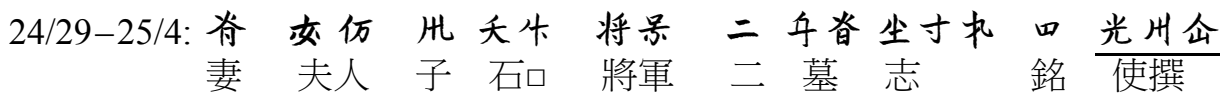

$$
\begin{aligned}
& \text { Wife madam son Shi } \square \text { General two epitaph let compile } \\
& \text { ([His] wife and son General Shi ? let [somebody] compile the epitaph) }
\end{aligned}
$$

According to Khitan custom, epitaphs, especially those erected for the Khitan, were compiled by a person invited by the family of the deceased or by a person assigned by the authorities. From the record above, we learned that this epitaph was compiled by Xi'nian invited by the epitaph owner's family, so the verb 光州企 of the sentence may be interpreted in the causative form, as 'let (somebody) compile'.

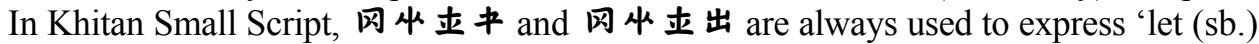
compile'. It has already been interpreted that 光州 corresponds to 网夾, which indicates that the Large Script 仚 corresponds to 走中 or 走出, read as 'yai' or 'yan'. According to the wording features of materials in the Khitan Small Script, 仚 is more likely to be read as 'yai'.

Except for the first two graphemes of the sequence 局两芥日灷兰 in the following part, the corresponding Small Script equivalents of the other four graphemes have already been confirmed previously, that is, 乔 $=$ 伏 (two times), 日 $=$ 天，兰 炎. The third and fifth graphemes are the same. According to the corresponding relations above, the last three graphemes correspond to the Small Script characters 天伏瓷 (Line 29 of Yelü Jue 耶律玦). Referring to the context of the block 天 伏公, the corresponding relation between 鬲先伏 and 局角灷is confirmed. Our proofs are 
as follows: the Large Script 7 also appears in Line 11 of the present epitaph to transliterate the Chinese character 察 of the official title 真泀觀察 (Guancha), while in other materials, the grapheme 苦 is used to transliterate the character 察 (Line 1 of Changyun 耶律昌允). Although there is a slight difference in the form of the two graphemes 局 and 周, they transliterate the same Chinese character and with the same meaning and pronunciation, so they may be variants to each other. In previous studies, it has been confirmed that 周 corresponds to 角 'ts $\mathrm{s}^{\text {' }} \mathrm{a}$ ', so 局 can also be read as

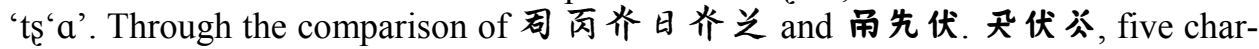
acters can well be determined, with the exception of the second character 页. Therefore, it is reasonable to suppose a relation between 丙 and 先. But the pronunciation of the Small Script grapheme 先 is unknown; therefore the pronunciation of the Large Script grapheme 而 cannot be reconstructed either.

\section{3. 高印䍐守仗 morning dew, 䀆苗北 night moon}

In the last 3 lines, there are Khitan graphemes with the meanings of 'a day and night', 'the third day' and 'the second month'; these are already interpreted words. But due to the present interpretation level, there are still some uninterpreted ones. Lines 29 to 35 are part of the epigraph, but the Khitan words contained therein are more difficult to interpret than the words in the part of the epitaph text. Applying the method of making use of the known to deduce the unknown, we have attempted to interpret some of these words.

For example, let us take the grapheme sequence 高印沓守仅 in Line 34 of the epitaph. The last two graphemes 守仅 mean 'dew'. Firstly, 守 is used in the words 守太扨 and 守太杲 to transliterate the Chinese words 守太尉 and 守太師, which is transliterated as 王空 炎 and 无空北 in the Khitan Small Script. Therefore, the

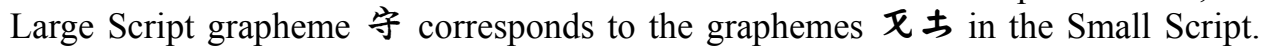
Secondly, the Khitan Small Script graphemes 㕣长公公 refer to a personal name, which can be interpreted as 'Pusuli' according to the Chinese inscription. It has already been proved that Pusuli is the husband of Shigu, the fourth daughter of Xiao Taishan (Liu Fengzhu 2014, p. 167). The name is written as 交仅左之 in the Large Script (Aisin Gioro 2009, p. 283), so 仅 corresponds to the grapheme $*$ in the Small Script. 守 equals to 支 and 仅 equals to 长, so the sequence 守仅 equals to 丈卡, which means 'dew', and can be read as 'Jousu' or 'Jous' (Wu Yingzhe 2007b, p. 2).

The Khitan Small Script graphemes 介玄 'spring', 公乃㐫 'autumn', 少及 'sweet' and 可术朳 'morning' always act as modifiers before the block 丈卡. From the pronunciation and the corresponding relations between large and Small Scripts, 高印苗 here may correspond to 可术术. According to previous studies, 高 is the transliteration of the Chinese character 百 (Liu Fengzhu 2014, pp. 523), read as 'bai' (Li Zhenhua-Zhou Changji 1999, p. 378) while 印 and 囬 are genitives which correspond the the Small Script graphemes 雨 and 作, read as 'in' and 'on'. Therefore, the sequence 高印苗 corresponds to 可雨术, which differs from 可术术 'morning', in that the second graphemes 雨 and 林 are different. But it has no effect on interpreting 
the sequence 高印䍐 as 'morning', because the genitive 本 has broad adaptability, it can replace other genitives like 雨, 夹 and '姑. In addition, there are some other examples that 高 corresponds to 可, read as 'bai': 可伞为出 (Line 19 of Han Dilie 韓 迪烈) is a personal name which is recorded as 擺撒 (baisa) in Chinese inscriptions. Therefore, it can be reconstructed as 'bai-is-ya-a-an'. On the basis of 高= 可, the personal names 可羊丹伏 (Line 1 of Xiao Chala 蕭查剌) in Small Script and 高已仃 (Line 3 of Liuyin 留隱) in Large Script also correspond to each other.

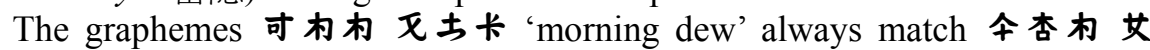
'night moon' in epigraphs in the Khitan Small Script, from which we have investigated that 高印苗守仅 'morning dew' are followed by 䀆苗 'of night'. The meaning of 䀆 has already been mentioned above. According to the wording habit of the Small Script, the grapheme 黑 followed by 'of night' may mean 'moon'. Both 'month' and 'moon' are written as 廿 in Small Script, so the two concepts could be written with the same grapheme in the Large Script as well. 月 'month' in the Large Script may also have the meaning of 'moon'. Therefore, the meaning of $A$ is temporarily unknown, and needs further study.

\section{4. 卫出 now, 真令文䍐 Guanzhong's}

In addition to the words interpreted so far, we may try to interpret some other Large Script graphemes and find out their corresponding Small Script equivalents.

尊番苗 in Line 1 may mean 'of the House of the Eldest Uncle', the beginning grapheme of which is different from 乎来沓 treated before. Further investigation is needed to explain the difference between 尊 and 买.

共共 in Line 8 may be the personal name 'Yanning'. This reading is based on the personal name 丈孔共守 'Di'nian Yanshou' (Line 7 of Yelü $Q i$ 耶律祺). The Large Script grapheme 共 corresponds to the Chinese character 延 (Yan), read as 'ian(2)' or 'ien (4)' (Li Zhenhua-Zhou Changji 1999, pp. 215, 243), while $介$ 介 is read as 'in'. Therefore, 共芥 is read as 'iannin' which is similar in pronunciation to the personal name 'Yanning' occurring in historical materials.

There are two graphemes $工$ 出 in Line 23, of which 1 corresponds to the Small Script grapheme 文, and 出 to 爸. Therefore, 工出 corresponds to 及炎 and means 'now'. The pronunciation needs further investigation.

There are four graphemes 真食户炎 in Line 27, the first one 真 is used to transliterate the Chinese character 觀 of the word 觀察 (真司), while the other two graphemes 念户 are used to transliterate the Chinese character 中 of the word 侍中 (杲含户) (Line 9 of Yelü $Q i$ 耶律祺). 䍐 is a genitive, therefore 真含之 may correspond to the Chinese characters 觀中, being similar in pronunciation to the graphemes 几及了了太必 in the Small Script (Line 47 of Xiao Zhonggong 蕭仲恭), the transliteration of the personal name 管仲 (Guanzhong). According to the proofs above, we can conclude that 真令灾苗 may mean 'Guanzhong's'.

In addition, in line with our investigation, 由至王昷 may mean 'Right Yuan Yilibi', and 早正行 may mean 'rest in peace' and 早正已日 may mean 'to remarry'. 


\section{Conclusion}

This paper aimed to systematically study the newly found Epitaph of Changgun Yelü Zhun of Great Liao 大遼國常衰耶律隼墓誌銘. Throughout our investigation, it has become quite clear that the epitaph owner Yelü Zhun had the name of 度 and the courtesy name of 徒央齐. He was of the Yaonian clans and the eighth generation descendant of Yaonian Xianzhi Khaan. His father was named Xiyin - Gaoliu Shizhong, and his uncle was Liuyin • Pusanu Changwen, Yelü Jue's father. Zhun and Jue were cousins.

In the present epitaph it is recorded that "In September Xianyong 1st year... appointed Changgun", while at another place "In September Xianyong 1st year... On Yihai of September, stop over at Ousi Dian. On Dingchou, Left Yilibi Lianning became Changwen of the House of the Eldest Uncle". 'Changgun' is evidently identical with 'Changwen'. It is not a coincidence that Lianning and Zhun were appointed the same position in the same month, the same year, so it can be deduced that the two are one and the same person. Zhun's wife was of the house of Telin Khaan of Six Tribes $\mathrm{Xi}$, named 总 married.

Zhun's family lineage is illustrated in Appendix I. From the information in Khitan Large Script it seems that Zhun was the heir of the house of his granduncle Xieling Lubugu Taiwei. Once Zhun held the post of 'Great General' 大將軍 (Da Jiangjun), 'Vice Commander of the Central Capital' 中京同知 (Zhong Jing Tongzhi), Governor of Matters of Dianzhong of Hangtai 知行台之殿中之事 (Zhi Hangtai zhi Dianzhong zhi Shi), General of Tianyun Army 天雲軍詳穩 (Tianyun Jun Xiangwen), 'Inspector’ 觀察使 (Guancha), ‘Superintendent of Five Yuan’ 五院都監 (Wuyuan Dujian), 'Inspecting grand tutor' 檢校太傅 (Jianjiao Taifu), 'Changgun of the House of the Eldest Uncle' 孟父常衰 (Mengfu Changgun), 'Feudal provincial governor' 諸州 刺史 (Zhuzhou Cishi), 'Provincial censor' 禦史 (Yushi), 'Military commissioner of Tongzhou' 同州之節度使 (Tongzhou Jiedushi), 'the governor of Fuzhou' 鄜州之事 知 (Fuzhou zhi Zhishi), 'Right Yuan Yilibi'右院夷離畢 (You Yuan Yilibi), 'Left Military General' 左武衛上將軍 (Zuo Wuwei Shang Jiangjun) etc.

On the basis of the rubbing of the present epitaph and the extant materials in Khitan Large Scripts, we have made the collation and check of the graphemes and fed the present epitaph text into a computer. This paper attempted to use the method of comparing the graphemes of the Large Script and the Small Script to deduce the unknown from the known. According to the new understanding of the nature of the Khitan Large Script and by investigating all kinds of Khitan materials, numerous Large Script graphemes matching with the corresponding Small Script graphemes have been found. Drawing on the research findings of the Khitan Small Script graphemes and the historical records of the Yaonian family, this paper tried to elucidate the wording habit and the combination rule of graphemes of the epitaph text as well as the context of the words, in order to decipher some Large Script graphemes untouched before and reconstruct or correct the pronunciation of some graphemes of the Large Script. We have also identified several groups of variants. The findings of the paper can be summed up as follows: 


\section{A. The Corresponding Relations between the Large and the Small Scripts}

\begin{tabular}{|c|c|c|c|}
\hline No. & Corresponding relation & Example & Meaning \\
\hline 1 & 大 $=$ 今中头 & \multirow{2}{*}{$\begin{array}{l}\text { 大伦允地印 }=\text { 今中头公炎 } \\
\text { 王雨 }\end{array}$} & \multirow{2}{*}{$\begin{array}{l}\text { Tigin (an official title) } \\
\text { of the Imperial Palace }\end{array}$} \\
\hline 2 & 地 =王炎 & & \\
\hline 3 & 州/月＝比 & 身州灷/身月芥＝口此伏 & Telin (a person's name) \\
\hline 4 & 王 $=$ 來 & \multirow[t]{2}{*}{ 王本二來立夹 } & \multirow[t]{2}{*}{ Khaan (Emperor) } \\
\hline 5 & 本 $=$ 来夹 & & \\
\hline 6 & 将 $=$ 伏 & \multirow{2}{*}{ 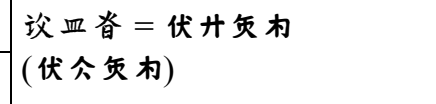 } & \multirow[t]{2}{*}{ of tribes } \\
\hline 7 & 血 $=$ 矢 & & \\
\hline 8 & 我 $=$ 全去 & \multirow{2}{*}{ 疾＝羊去机 } & \multirow{2}{*}{ Xianzhi (Emperor) } \\
\hline 9 & 䧹 $=$ 机 & & \\
\hline 10 & 歨 $=$ 用丹 & 正疶 =用丹机 & Yilibi (an official title) \\
\hline 11 & 州 = 斿 & 州共 $=$ 苊伏 & $\begin{array}{l}\text { Chounü (a person's } \\
\text { name) }\end{array}$ \\
\hline 12 & 及 $=$ 马 & 夭反 = 丈兴马 & Shizhu (official title) \\
\hline 13 & 天 $=$ 列艺 & 芥 = 列䒔及杏 & $\begin{array}{l}\text { Heshuwen (a person's } \\
\text { name) }\end{array}$ \\
\hline 14 & 四=六 & \multirow{2}{*}{ 四灹之 $=$ 六丹公 } & \multirow{2}{*}{$\begin{array}{l}\text { Duoluwo (a person's } \\
\text { name) }\end{array}$} \\
\hline 15 & 灹 $=$ 丹 & & \\
\hline 16 & Ht $=$ 公 & 来州 $=$ キ公 & male kids \\
\hline 17 & 吉 $=$ 军 & 来化任石古 & male kids four \\
\hline 18 & 把 =西 & 把不 =面头 & $\begin{array}{l}\text { to inherit the ancestral } \\
\text { temple }\end{array}$ \\
\hline 19 & 䀆 $=$ 全杏 & 䀆日不凩=全杏天头穴 & $\begin{array}{l}\text { Ye Ri officer (an offi- } \\
\text { cial title) }\end{array}$ \\
\hline 20 & 近 $=$ 公企 & 近他 $=$ 公企爸 & relatives \\
\hline 21 & 夯 $=$ 㞋 & \multirow{2}{*}{ 开寺 $=$ 屋及㜾矢 } & \multirow{2}{*}{ manage to } \\
\hline 22 & 开 $=$ 及㜾 & & \\
\hline 23 & 玍 $=$ 及态 / 仍头 & 午寺卷 $=$ 头化矢及态 & $\begin{array}{l}\text { to supplement a title (to } \\
\text { be examined further) }\end{array}$ \\
\hline 24 & 是 $=$ 火全 & $\begin{array}{l}\text { 是券方 }=\text { 火金㕕火 } \\
\text { (火金火) }\end{array}$ & $\begin{array}{l}\text { morning (to be ex- } \\
\text { amined further) }\end{array}$ \\
\hline 25 & 佐 $=$ 尘 & 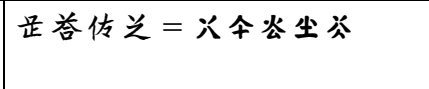 & $\begin{array}{l}\text { morning (to be ex- } \\
\text { amined further) }\end{array}$ \\
\hline
\end{tabular}




\begin{tabular}{|c|c|c|c|}
\hline No. & Corresponding relation & Example & Meaning \\
\hline 26 & 仚 $=$ 五中 / 五出 & 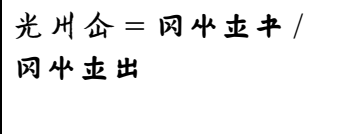 & $\begin{array}{l}\text { let (somebody) compile } \\
\text { (to be examined fur- } \\
\text { ther) }\end{array}$ \\
\hline 27 & 君 = 角 & \multirow{2}{*}{ 君丙芥 $=$ 而先伏 } & \multirow{2}{*}{$\begin{array}{l}\text { before (to be examined } \\
\text { further) }\end{array}$} \\
\hline 28 & 丙 $=$ 先 & & \\
\hline 29 & 高 $=$ 可 & 高印炎 $=$ 可木杭 & of morning \\
\hline $30^{1}$ & $\begin{array}{l}\text { 日 }=\text { 天 } \quad \text { 共 }=\text { 伏 } \\
\text { 之 }=\text { 公 }\end{array}$ & 日乔兰 $=$ 天伏公 & days \\
\hline 31 & 索=而 来 $=$ 交 & 索来 =而交 & army \\
\hline 32 & 未 $=$ 圠 手 $=$ 为夹 & 未乎 $=$ 圠为夹 & after \\
\hline 33 & 守 $=$ 丈古 $\quad$ 仅 $=$ 长 & 守仅 = 王去 & dew \\
\hline 34 & $\begin{array}{ll}\text { 早=力 } & \text { 正 }=\text { 冬 } \\
\text { 已 }=\text { 全 } & \text { 日 }=\text { 比 }\end{array}$ & 早正已日 = カ冬全比 & to remarry \\
\hline 35 & ユ=及出 $=$ 炎 & 工出 $=$ 及炎 & now \\
\hline 36 & 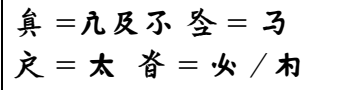 & 户炎 = 九及不 万太必 & $\begin{array}{l}\text { Guanzhong's (a } \\
\text { person's name) }\end{array}$ \\
\hline
\end{tabular}

\section{B. Variants}

\begin{tabular}{|c|c|c|c|c|}
\hline No. & Large Script & Origin & Large Script & Origin \\
\hline \multirow[t]{2}{*}{1} & \multirow[t]{2}{*}{ 不 } & \multirow{2}{*}{$\begin{array}{l}\text { Line } 1 \text { Yelü Zhun } \\
\text { 耶律凖 }\end{array}$} & 지 & Line 1 Yelü Xinie 耶律習涅 \\
\hline & & & 31 & Line 1 Yongning Jun 永寧郡 \\
\hline 2 & 月 & $\begin{array}{l}\text { Line } 1 \text { Yelü Zhun } \\
\text { 耶律凖 }\end{array}$ & 可 & Line 1 Yongning Jun 永寧郡 \\
\hline \multirow[t]{2}{*}{3} & \multirow[t]{2}{*}{ 化 } & \multirow{2}{*}{$\begin{array}{l}\text { Line } 4 \text { Yelü Zhun } \\
\text { 耶律凖 }\end{array}$} & 此 & Line 1 Tulibu 突裡不 \\
\hline & & & 此 & Line 2 Tulibu 突裡不 \\
\hline 4 & 周 & $\begin{array}{l}\text { Line } 11 \text { Yelü Zhun } \\
\text { 耶律凖 }\end{array}$ & 周 & Line 1 Changyun 昌允 \\
\hline 5 & 奐 & \begin{tabular}{|l} 
Line 13 Yelü Zhun \\
耶律凖
\end{tabular} & 㚖 & Line 8 Yelü $Q i$ 耶律祺 \\
\hline 6 & 穴 & $\begin{array}{l}\text { Line } 23 \text { Yelü Zhun } \\
\text { 耶律凖 }\end{array}$ & 元 & Line 36 Yelü Zhun 耶律凖 \\
\hline
\end{tabular}

${ }^{1}$ The corresponding relationships of the scripts Nos 30 to 36 have been proved by scholars, so this paper only intends to propose some views on some pairs of compound characters. 


\section{Pronunciation}

\begin{tabular}{|c|c|c|c|c|}
\hline No. & Large Script & Pronunciation & \multicolumn{2}{|l|}{ Example } \\
\hline 1 & 大 & dai & 大伦允 & imperial palace \\
\hline 2 & 地 & $\mathrm{ti}$ & 地印 & Tigin (an official title) \\
\hline 3 & 月 & li & 身芥 & Telin (a person's name) \\
\hline 4 & 王 & $\mathrm{xa}$ & \multirow{2}{*}{ 王本 } & \multirow{2}{*}{ Khaan (Emperor) } \\
\hline 5 & 本 & yan & & \\
\hline 6 & 将 & $\mathrm{n}$ & \multirow{2}{*}{ 挴放血䍐 } & \multirow{2}{*}{ of tribes } \\
\hline 7 & 皿 & li & & \\
\hline 8 & 乎 & sen & \multirow{2}{*}{ 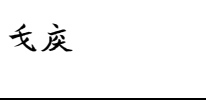 } & \multirow{2}{*}{ Xianzhi (Emperor) } \\
\hline 9 & 疛 & t & & \\
\hline 10 & 正 & $\mathrm{irb} \sim \mathrm{ilb}$ & 正尿 & Yilibi (an official title) \\
\hline 11 & 州 & $\operatorname{tsc}^{6} \mathrm{u} \sim \mathrm{fg}^{\mathrm{c}} \mathrm{u}$ & 州乔 & Chounü (a person's name) \\
\hline 12 & 天 & h-atfu & 天岙 & Heshuwen (a person's name) \\
\hline 13 & 四 & $\mathrm{t}$ & \multirow{2}{*}{ 四灹之 } & \multirow{2}{*}{ Duoluwo (a person’s name) } \\
\hline 14 & 杔 & lu & & \\
\hline 15 & 㤙 & tur & 番北任百 由 & male kids four \\
\hline 16 & 䀆 & sun suni & 苗日不瓦 & Ye Ri officer (an official title) \\
\hline 17 & 近 & nam & 近忚 & relatives \\
\hline 18 & 开 & udzu & 夷开寺 & manage to \\
\hline 19 & 是 & xis / kis & 是兴㐫 & \\
\hline 20 & 伖 & $\mathrm{t}$ & 是兴伖兰 & \\
\hline 21 & 金 & yai / yan (?) & 光州仚 & let (somebody) compile \\
\hline 22 & 周 & ts $\mathrm{s}^{\prime} \mathrm{a}$ & 真局 & inspector \\
\hline 23 & 高 & $\mathrm{ba} \sim$ bai & 高印苗 & of morning \\
\hline 24 & 1 & ed & 工出 & now \\
\hline
\end{tabular}

\section{Meaning}

\begin{tabular}{|c|c|c|c|c|}
\hline No. & Large Script & Meaning & \multicolumn{2}{|l|}{ Example } \\
\hline 1 & 尊 & the eldest & 尊事苗 & of the Eldest Uncle \\
\hline 2 & 大 & big, large & \multirow{2}{*}{ 大伦允 地印 } & \multirow{2}{*}{$\begin{array}{l}\text { Tigin of Imperial } \\
\text { Palace }\end{array}$} \\
\hline 3 & 地 & $\mathrm{Ti}$ & & \\
\hline 4 & 身州共 & Telin (a person's name) & \multirow{2}{*}{ 身州芥王本 } & \multirow{2}{*}{ of Telin Khaan } \\
\hline 5 & 国本 & of Khaan (Emperor) & & \\
\hline
\end{tabular}




\begin{tabular}{|c|c|c|c|c|}
\hline No. & Large Script & Meaning & \multicolumn{2}{|l|}{ Example } \\
\hline 6 & 捊讼血苗 & of tribes & 求将讼血䍐 & of six tribes \\
\hline 7 & 车尿 & Xianzhi (Emperor) & $\begin{array}{l}\text { 头扎我应 } \\
\text { 国本 }\end{array}$ & $\begin{array}{l}\text { of Dinian Xianzhi } \\
\text { Khaan }\end{array}$ \\
\hline 8 & 正应 & Yilibi (an official title) & 早勾关正疾 & Royal Uncle Yilibi \\
\hline 9 & 州芥俣 & $\begin{array}{l}\text { Chounü San (a person's } \\
\text { name) }\end{array}$ & \multirow{2}{*}{ 州共 俣 天及 } & \multirow{2}{*}{$\begin{array}{l}\text { Chounü San (a per- } \\
\text { son's name) Shizhu } \\
\text { (an official title) }\end{array}$} \\
\hline 10 & 夭及 & Shizhu (an official title) & & \\
\hline 11 & 天齐 & $\begin{array}{l}\text { Heshuyin (a person's } \\
\text { name) }\end{array}$ & \multirow{2}{*}{ 天界四灹兰 } & \multirow{2}{*}{$\begin{array}{l}\text { Heshuyin Duoluwo } \\
\text { (a person's name) }\end{array}$} \\
\hline 12 & 四灹之 & $\begin{array}{l}\text { Duoluwo (a person's } \\
\text { name) }\end{array}$ & & \\
\hline 13 & 单芥 & Xiyin (a person's name) & \multirow{2}{*}{ 屏芥充充 } & \multirow{2}{*}{$\begin{array}{l}\text { Xiyin Gaoliu (a per- } \\
\text { son's name) }\end{array}$} \\
\hline 14 & 充㐬 & Gaoliu (a person's name) & & \\
\hline 15 & 四灹兰 & the seventh & 四灹兰冬苗 & $\begin{array}{l}\text { of the seventh gen- } \\
\text { eration }\end{array}$ \\
\hline 16 & 番性 & male & \multirow{2}{*}{ 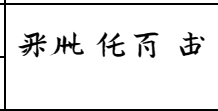 } & \multirow{2}{*}{ male kids four } \\
\hline 17 & 甹 & four & & \\
\hline 18 & 把不 & to inherit & 皿把不 & $\begin{array}{l}\text { to inherit the an- } \\
\text { cestral temple }\end{array}$ \\
\hline 19 & 尘 & night & 䀆日不瓦 & $\begin{array}{l}\text { Ye Ri officer (night } \\
\text { and day officer) }\end{array}$ \\
\hline 20 & 早幻 & died young & \multirow[t]{2}{*}{ 早幻未手 } & \multirow{2}{*}{ after died young } \\
\hline 21 & 未手 & after & & \\
\hline 22 & 真君 & to inspect & 真局杲 & inspector \\
\hline 23 & 近㤞 & relatives & 近忚克来 & relative uncle \\
\hline 24 & 英开寺 & manage to & 允夷形寺 & manage to \\
\hline 25 & 索来 & army & 禾云去来 & Tianyun Army \\
\hline 26 & 尖 & to confer, to supplement & 午寺尖 & to supplement a title \\
\hline 27 & 光州㕕 & let compile & $\begin{array}{l}\text { 年囬尘寸れ } \\
\text { 四光州企 }\end{array}$ & $\begin{array}{l}\text { let somebody com- } \\
\text { pile the epitaph text }\end{array}$ \\
\hline 28 & 日共兰 & days & $\begin{array}{l}\text { 君页芥 } \\
\text { 日灷之 }\end{array}$ & $\square \square$ days \\
\hline 29 & 高印䍐 & of morning & \multirow[t]{2}{*}{ 高印䍐守仗 } & \multirow[t]{2}{*}{ morning dew } \\
\hline 30 & 守仅 & dew & & \\
\hline 31 & 工出 & now & 工出岑几 & now $\square \square$ \\
\hline
\end{tabular}




\begin{tabular}{|c|c|c|c|c|}
\hline No. & Large Script & Meaning & \multicolumn{2}{|l|}{ Example } \\
\hline 32 & 真令文䍐 & $\begin{array}{l}\text { Guan Zhong ( a person's } \\
\text { name) }\end{array}$ & 真令户䍐 & $\begin{array}{l}\text { Guan Zhong's (a per- } \\
\text { son's name) }\end{array}$ \\
\hline 33 & 早正已日 & to remarry & $\begin{array}{l}\text { 早正已日 } \\
\text { 员之 }\end{array}$ & bore after remarry \\
\hline 34 & 由至王昷 & Right Yuan & $\begin{array}{l}\text { 迪至东昷 } \\
\text { 疋卫 }\end{array}$ & $\begin{array}{l}\text { Right Yuan Yilibi (an } \\
\text { official title) }\end{array}$ \\
\hline 35 & 早正行 & rest in peace & 早正行 手 & rest in peace tomb \\
\hline
\end{tabular}

\section{Abbreviations}

\section{[1] The Short Names of the Materials in the Khitan Large Script and Their Full Names}

Yelü Zhun 耶律凖: Epitaph of Changgun Yelü Zhun of Great Liao 大遼國常衰耶律凖墓誌銘 Liuyin 留隱: Epitaph of Taishi Yelü Liuyin 耶律留隱太師墓誌銘 Yelü Qi 耶律祺: Epitaph of Yüyue Yelü Qi 耶律祺於越墓誌銘 Yongning Jun 永寧郡: Epitaph of Princess Yongning Jun 永寧郡公主墓誌銘 Xiao Xiaozhong 蕭孝忠: Epitaph of Jiedushi Xiao Xiaozhong 蕭孝忠節度使墓誌銘 Xiao Paolu 蕭袍魯: Epitaph of Late Northern Chancellor Xiaogong 故北宰相蕭公墓誌銘 Tulibu 突裡不: Epitaph of Yelü Tulibu Langjun 耶律突裡不郎君墓誌 Yelü Xinie 耶律習涅: Epitaph of Jiedushi of Great Tent 大横帳節度副使墓誌銘 Changyun 昌允: Epitaph of Taishi Yelü Changyun 耶律昌允太師墓誌名 Beidawang 北大王: Epitaph of the Great Prince of the North 北大王墓誌

\section{[2] The Short Names of the Materials in the Khitan Small Script and Their Full Names}

Zongjiao 宗教: Epitaph of Guangling Junwang of Great Khitan State 大契丹國廣陵郡王墓誌銘 Yelü $N u$ 耶律奴: Epitaph of Yelü Nu Xiangwen 耶律奴詳穩墓誌銘 Tuguci 圖古辭: Epitaph of Tuguci Shangshu 蕭圖古辭尚書墓誌銘 Gaoshi 高十: Epitaph of Han Gaoshi Linggong 韓高十令公墓志

Dilu 敵魯: Epitaph of Xiao Dilu Fushi 蕭敵魯副使墓誌銘

$X u$ Wang 許王: Epitaph of Xu Wang of Liao 遼國許王墓誌

Zhenguo 鎮國: Epitaph of Great General Zhenguo 鎮國上將軍墓誌銘

Yelü Xiangwen 耶律詳穩: Epitaph of Yelü Xiangwen 耶律詳穞墓誌

Yelü Jue 耶律玦: Epitaph of Changwen Yelü Jue 耶律玦敞穩墓誌銘

Yelü Taishi 耶律太師: Epitaph of Yelü Taishi 耶律太師墓誌銘

Zhixian 智先: Epitaph of Taiwei Yelü Zhixian 耶律智先太尉墓誌銘

Yongqing 永清: Epitaph of General Xiao Taishan and Yongqing Princess 蕭太山將軍永清郡主 墓誌

Xiao Chala 蕭查剌: Epitaph of Xiao Chala Xianggong 蕭查刺相公墓誌銘

Wumo 兀沒: Epitaph of Fubushu Yelü Wumo 耶律沒副部署墓誌銘

Yelü Dilie 耶律迪烈: Epitaph of the Late Prince Dilie of Great Liao of Jambu-dvipa 南贍部洲大 遼國故迪烈王墓誌文 
Han Dilie 韓迪烈: Epitaph of Taibao Yelü (Han) Dilie 耶律（韓）迪烈太保墓誌銘 Xiao Zhonggong 蕭仲恭: Epitaph of Prince Xiao Zhonggong of Yue Guo 越國王蕭仲恭墓誌銘

\section{References}

Aisin Gioro Ulhicun 愛新覚羅·烏拉熙春 (2009): Isinkakura urakisyun kixtutan jyosin gaku kenkyuu 『愛新覚羅·烏拉熙春契丹女真学研究』[Aisin Gioro Ulhicun’s studies on Khitan and Jurchen]. Kyoto, Matsu Kaorudo Bookstore.

Aisin Gioro Ulhicun 愛新覚羅·烏拉熙春 - Yoshimoto Michimasa 吉本道雅 (2011): Kanhantou kara nagameta kittan to jyosin 『韓半島から眺めた契丹と女真』[On Khitan and Jurchen viewed from the Korean Peninsula]. Kyoto, Kyoto University Press.

Aisin Gioro Ulhicun 愛新覚羅·烏拉熙春 - Yoshimoto Michimasa 吉本道雅 (2012): Sinsyutu kittan siryou no kenkyuu 『新出契丹史料の研究』[Research on newly found Khitan historical materials]. Kyoto, Matsu Kaorudo Bookstore.

Chinggeltei 清格爾泰 - Liu Fengzhu 劉鳳翥-Chen Naixiong 陳乃雄 - Yu Baolin 于寶林 - Xing Fuli 邢複禮 (1985). Qidan xiaozi yanjiu 《契丹小字研究》 [Research on Khitan Small Script]. Beijing, Zhongguo shehui kexue chubanshe.

Haneda Tōru 羽田享 (1925): Kittan moji no sinsiryou「契丹文字の新資料」 [New material for the study of the Kitan Script]. 『史林』Shirin Vol. 10, No. 1, pp. 82-96.

Hitoshi Kuribayashi 栗林均-Choijinjab 确精扎布 (2001): “Gentyouhishi” mongurugo zentango·gobisakuin『“元朝秘史”モンゴル语全单语·语尾索引』[Word- and suffix-index to the Secret History of the Mongols based on the Romanised transcription of L. Ligeti]. Sendai, Northeastern Asia Study Centre of Tohoku University.

Ji Shi 即實 (1996): Milin Wenjing - Qidan Xiaozi Jiedu Xincheng 《謎林問徑一契丹小字解讀 新程》 [Seeking a path through the forest of riddles: a new stage in the decipherment of the Khitan Script]. Shenyang, Liaoning minzu chubanshe.

Ji Shi 即實 (2012): Mitian gengyun - Qidan xiaozi jiedu xu 《謎田耕耘一契丹小字解讀續》 [Ploughing through the field of riddles - continued study on the interpretation of Khitan Small Script]. Shenyang, Liaoning Minzu Chubanshe.

Li Dingkui 庽鼎煃 (1932): Rehe Qidanguo Shubeikao 《熱河契丹國書碑考》 [A study of the Stelae in the Khitan National Script in Rehe]. Guoxue jikan Vol. 3, No. 4, pp. 563-572.

Li Zhenhua 李珍華-Zhou Changji 周長楫 (1999): Hanzi Guyin Biao (Xiudingban) 《漢字古今 音表》（修訂本） [The ancient and modern Chinese character sound table (Revised edition)]. Beijing, Zhonghua Shuju.

Liu Fengzhu 劉鳳翥 (2014): Qidan Wenzi Yanjiu Leibian (Di Er Ce)《契丹文字研究类编》 (第二册) [Collection of studies on Khitan scripts]. Vol. 2. Beijing, Zhonghua Chubanshe.

Liu Fengzhu 劉鳳翥-Tang Cailan 唐彩蘭等-Qinggele 青格勒 (2009): Liaoshangjing Diqu Chutu de Liaodai Beike Huiji 《遼上京地區出土的遼代碑刻匯輯》[Collection of inscriptions of Liao Dynasty of Liao Shang Jing Area]. Beijing, Shehui Kexue Wenxian Chubanshe.

Liu Fengzhu 劉鳳翥-Wang Yunlong 王雲龍 (2004): Qidan Dazi Yelü Changyun Muzhiming zhi Yanjiu《契丹大字〈耶律昌允墓誌銘〉之研究》[Research on the Epitaph of Yelü Changyun in the Khitan Large Script]. Yenching Journal of Chinese Studies No. 17, pp. 61-99.

Liu Pujiang 劉浦江 (2011): Zailun Qidanren de Fuzi Lianmingzhi - Yi Jinnian Chutu de Qidan Da Xiaozi Shike wei Yanjiu Zhongxin 《再論契丹人的父子連名制一以近年出土的契丹大小 字石刻為中心》[Further discussion on patronymic linkage naming system - focusing on recently unearthed inscriptions in Khitan Large and Small Script]. Vol. 1. Beijing, Qinghua Yuanshi. 
Luo Fucheng 羅福成 (1934): Daozong Huangdi ji Xuanyi Huanghou Guoshu Aice Kao 《道宗皇 帝及宣懿皇后國書哀冊考》 [A study of the funerary inscriptions of Emperor Daozong and the Empress Xuanyi]. In: Jin Yufu 金毓桷 (ed.): Liaoling Shike Jilu 遼陵石刻集錄 [A collection of stone inscriptions of the Liao Mausoleum]. Vol. 4. Fengtian, Fengtian Library, pp. $113-121$.

Murayama Shichiro 村山七郎 (1951): Kittanji kaidoku no houhou「契丹字解読の方法」[Methodology for deciphering the Khitan Script]. Gengo kenkyu 『言語研究』March 1951, Nos 17/18, pp. 47-69, 182-185.

Osada Natsuki 長田夏樹 (1951): Kittan moji no kanousei - Murayama Sitiro-Si no nonnbun no yomide「契丹文字解読の可能性一村山七郎氏の論文の読みて」 [The possibility of deciphering the Khitan Script]. Kobe Daigaku Ronso 『神戸外大論叢』Vol. 2, No. 4, pp. $44-66$.

Wang Jingru 王靜如 (1933): Liao Daozong ji Xuanyi Huanghou Qidanguozi Aice Chushi 《遼道 宗及宣懿皇后契丹國字哀冊初釋》 [A preliminary explanation of the eulogies of Daozong and Empress Xuanyi of the Liao in the Khitan Script]. Lishi Yuyan Yanjiusuo Jikan No. 3, Part 4, pp. 467-478.

Wu Yingzhe 吳英吉 (2007a): Qidanyu Jingci Yufa Fanchou Yanjiu 《契丹語靜詞語法範疇研 究》 [Research on nominal grammatical categories of the Khitan language]. Hohhot, Inner Mongolia University Publishing House.

Wu Yingzhe 吳英喆 (2007b): Qidan Xiaozi ‘Zhaolu Yueye’ Kao 契丹小字 “朝露夜月” 考 [Explanation of 'Morning Dew and Night Moon' in Khitan Small Script]. Journal of Inner Mongolia University 3rd Issue, p. 2.

Yamaji Hiroaki 山路広明 (1956): Kittan seiji no kenkyuu 『契丹製字の研究』[Research on the structure of the Khitan Script]. Tokyo, Ajia Afurika Gengo Kenkyushitsu.

[Yuan] Tuotuo 脫脫 et al. (1974): Liaoshi Juan 96 Yelü Liang Zhuan 《遼史》卷 96 《耶律良 傳》 [History of Liao, Volume 96: Biography of Yelü Liang]. Beijing, Zhonghua Shuju. 


\section{APPENDIX I}

\section{Yelü Zhun's Family Genealogical Table}

Zhun and Jue, who are the epitaph owners of the Epitaph of Changgun Yelü Zhun of Great Liao (1068) in Large Script and the Epitaph of Changwen Yelü Jue (1071) in Small Script, are cousins. Both of them are the descendants of Dinian Xianzhi Khaan. Referring to the findings of previous studies and our interpretation of these two epitaphs, we have corrected and supplemented Yelü Zhun's family lineage as follows:

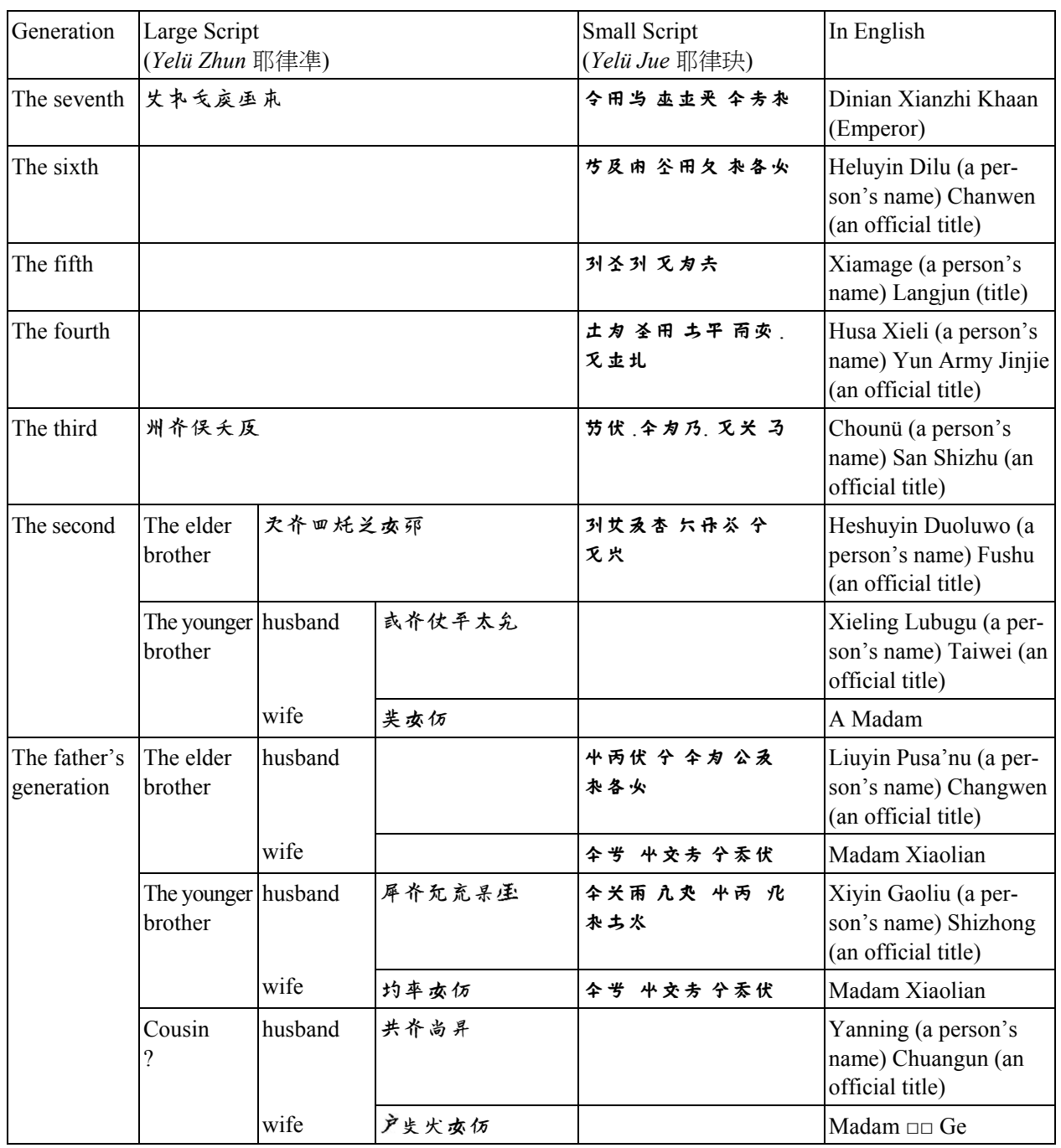




\begin{tabular}{|c|c|c|c|c|c|c|}
\hline Generation & \multicolumn{4}{|c|}{$\begin{array}{l}\text { Large Script } \\
\text { (Yelü Zhun 耶律凖) }\end{array}$} & $\begin{array}{l}\text { Small Script } \\
\text { (Yelü Jue 耶律玦) }\end{array}$ & In English \\
\hline \multirow{13}{*}{$\begin{array}{l}\text { Of the same } \\
\text { generation of } \\
\text { the epitaph } \\
\text { owner }\end{array}$} & \multirow{7}{*}{$\begin{array}{l}\text { The sons } \\
\text { and daugh- } \\
\text { ters of Liu- } \\
\text { yin Pusanu }\end{array}$} & The eldest & \multirow{2}{*}{\multicolumn{2}{|c|}{ husband }} & 㜾当岀机各必 & $\begin{array}{l}\text { Wuzhanwu (a person's } \\
\text { name) Changgun (an } \\
\text { official title) }\end{array}$ \\
\hline & & & & & 几夾 几炎 今冬伏 & Madam Guige \\
\hline & & The second & & & 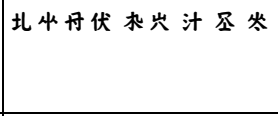 & $\begin{array}{l}\text { Wuluben Zhufen (a } \\
\text { person's name) Taiwei } \\
\text { (an official title) }\end{array}$ \\
\hline & & \multirow[t]{2}{*}{ The third } & \multirow{2}{*}{\multicolumn{2}{|c|}{ husband }} & 乃列为尔夾 & Lady Amuha (?) \\
\hline & & & & & 圼用 更为共 & $\begin{array}{l}\text { Xieli (a person's name) } \\
\text { Langjun (an official } \\
\text { title) }\end{array}$ \\
\hline & & The fourth & & & 旮九爸 尔夾 & $\square$ Lady \\
\hline & & The fifth & & & 䒘方友头㜾与爸中比 & $\square$ master \\
\hline & \multirow{6}{*}{$\begin{array}{l}\text { Xiyin Gao- } \\
\text { liu's sons } \\
\text { and daugh- } \\
\text { ters }\end{array}$} & $\begin{array}{l}\text { The elder } \\
\text { brother }\end{array}$ & \multicolumn{2}{|c|}{ 备芥鬼㐬之公 } & 居坐同九必 & $\begin{array}{l}\text { Dilie (a person's name) } \\
\text { Linggong (an official } \\
\text { title) }\end{array}$ \\
\hline & & $\begin{array}{l}\text { The epitaph } \\
\text { owner }\end{array}$ & \multicolumn{2}{|c|}{ 徒果芥尚开 } & & $\begin{array}{l}\text { Zhun, Zaogu (a per- } \\
\text { son's name) Changgun } \\
\text { (an official title) }\end{array}$ \\
\hline & & $\begin{array}{l}\text { The younger } \\
\text { brother }\end{array}$ & \multicolumn{2}{|c|}{ 丁乔徒龟将开 } & & $\square$ General \\
\hline & & $\begin{array}{l}\text { The younger } \\
\text { brother }\end{array}$ & \multicolumn{2}{|c|}{ 丁炏光出 } & & $\begin{array}{l}\text { Chen'ge (a person's } \\
\text { name) Langjun (an of- } \\
\text { ficial title) }\end{array}$ \\
\hline & & \multirow{2}{*}{$\begin{array}{l}\text { The younger } \\
\text { sister }\end{array}$} & \multirow{2}{*}{$\begin{array}{l}\text { husband } \\
\text { wife }\end{array}$} & 备杲 & & \\
\hline & & & & \begin{tabular}{|l|} 
何至走吾 \\
臣天
\end{tabular} & & The Han $\square$ 's \\
\hline \multirow{5}{*}{$\begin{array}{l}\text { The younger } \\
\text { generation }\end{array}$} & \multirow{5}{*}{$\begin{array}{l}\text { Sons and } \\
\text { daughters } \\
\text { of epitaph } \\
\text { owner }\end{array}$} & son & \multicolumn{2}{|l|}{ 天床将号 } & & $\square$ General \\
\hline & & \multirow{2}{*}{$\begin{array}{l}\text { The eldest } \\
\text { daughter }\end{array}$} & \multirow{2}{*}{$\begin{array}{l}\text { wife } \\
\text { husband }\end{array}$} & 交大久 & & Lady Fuge \\
\hline & & & & 交否将号 & & General Fu $\square$ \\
\hline & & \multirow{2}{*}{$\begin{array}{l}\text { The second } \\
\text { daughter }\end{array}$} & \multirow[b]{2}{*}{ husband } & 重杲交仍 & & Madam $\square$ \\
\hline & & & & $\begin{array}{l}\text { 州扎有 } \\
\text { 太杲 }\end{array}$ & & $\begin{array}{l}\square \text { Taishi (an official } \\
\text { title) }\end{array}$ \\
\hline & \multirow{5}{*}{$\begin{array}{l}\text { Cousin } \\
\text { Yelü Jue's } \\
\text { sons and } \\
\text { daughters }\end{array}$} & \multirow{2}{*}{$\begin{array}{l}\text { The eldest } \\
\text { daughter }\end{array}$} & \multirow{2}{*}{$\begin{array}{l}\text { wife } \\
\text { husband }\end{array}$} & & 圠夾丹伏 尔夾 & Lady Wuluben \\
\hline & & & & & 斗茶伏 灭为共 & $\begin{array}{l}\text { Hudujin (a person's } \\
\text { name) Langjun (an of- } \\
\text { ficial title) }\end{array}$ \\
\hline & & \multirow{2}{*}{$\begin{array}{l}\text { The second } \\
\text { daughter }\end{array}$} & \multirow{2}{*}{$\begin{array}{l}\text { wife } \\
\text { husband }\end{array}$} & & 火卉交及尔夾 & Lady $\square$ \\
\hline & & & & & 空用与进劣 & $\begin{array}{l}\text { Di'nian (a person's } \\
\text { name) Situ (an official } \\
\text { title) }\end{array}$ \\
\hline & & $\begin{array}{l}\text { The third } \\
\text { daughter }\end{array}$ & & & 王及 尔夾 & Lady Agu \\
\hline
\end{tabular}




\begin{tabular}{|c|c|c|c|c|}
\hline Generation & \multicolumn{2}{|l|}{$\begin{array}{l}\text { Large Script } \\
\text { (Yelü Zhun 耶律凖) }\end{array}$} & \multirow{2}{*}{\begin{tabular}{|l} 
Small Script \\
(Yelü Jue 耶律玦)
\end{tabular}} & \multirow{2}{*}{\begin{tabular}{|l} 
In English \\
$\begin{array}{l}\text { Gaoshi (a person's } \\
\text { name) Zuofu (an offi- } \\
\text { cial title) }\end{array}$
\end{tabular}} \\
\hline & son & husband & & \\
\hline & & wife & 又及栄籴为出 尔炎 & Lady $\square$ \\
\hline & $\begin{array}{l}\text { The fourth } \\
\text { daughter }\end{array}$ & & 岀同夾丸尔夾 & Lady Yongliao (?) \\
\hline
\end{tabular}

\section{Interpretation of the Epitaph of Changgun Yelü Zhun of Great Liao in Khitan Large Script}

\section{Cover Stone}

1. 大辽國 (Great Liao State)

2. 常 衰 (Changgun)

3. 耶 律凖 ${ }^{2}$ (Yelü Zhun)

\section{Text of the Epitaph}

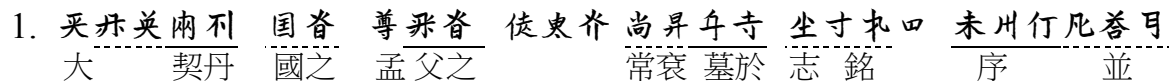
Great Khitan State of Mengfu of Changgun epitaph preface with

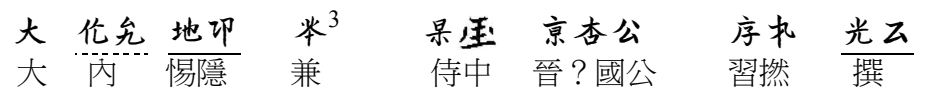
Great inside Tigin concurrently Shizhong Jin? Guogong Xi'nian compile

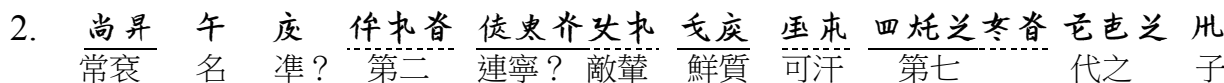
Changgun name Zhun? the second Zaogu? Di'nian Xianzhi Khaan the seventh generation of son

${ }^{2}$ According to the online Dictionary of Chinese Character Variants of China's Ministry of Education (http://dict2.variants.moe.edu.tw/variants/), this character is the variant of 凖.

${ }^{3}$ This paper intends to make the English translation correspond to the Khitan graphemes, so the original spaces in the epitaph text, which express respect, emphasis or separation of different contents, are ignored. 


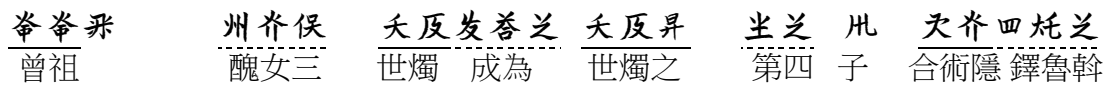

Great-grandfather Chounü San Shizhu became Shizhu of the fourth son Heshuyin Duoluwo

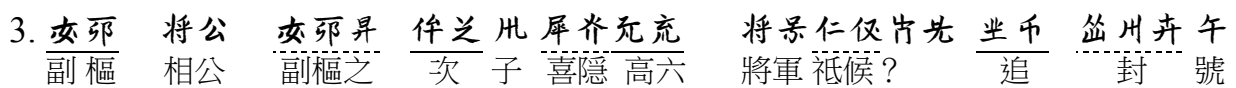

Fushu Xianggong Fushu's the 2nd son Xiyin Gaoliu General Zhihou? posthumous confer title

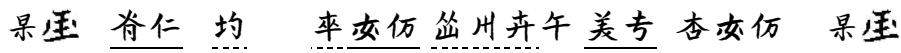

侍中妻 (人名) 夫人 封號一或夫人 侍中

Shizhong wife (name) Madam confer title Guo Madam Shizhong

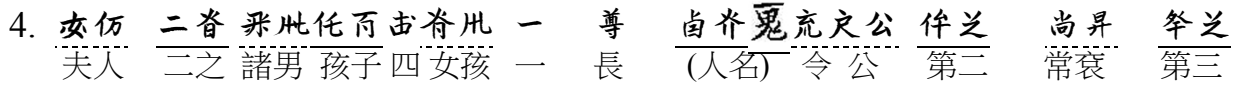
Madam two of males kids four girl one the eldest (name) Linggong the 2nd Changgun the 3rd

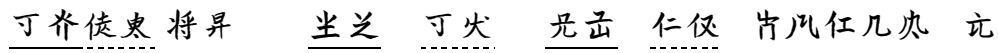
陳口詳穞第四陳哥郎君 祗候? 金 Chen $\square$ Xiangwen the 4th Chen Ge Langjun Zhihou? Jin

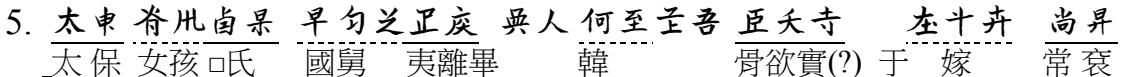
Taibao girl 口's royal uncle Yilibi Han Guyushi? to marry Changgun

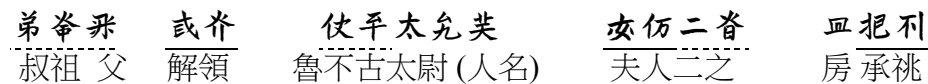
granduncle Xieling Lubugu Taiwei (name) Madam two of House to inherit

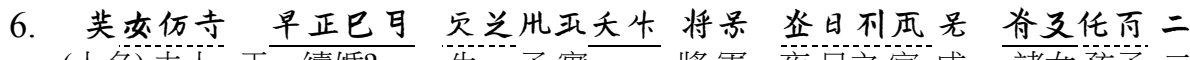
(人名) 怣人于 續婚? 生 子實口 將軍 夜白之官成諸女孩子二 (name) Madam to remarry? bore son Shi $\square$ General Ye Ri of officer became girls two

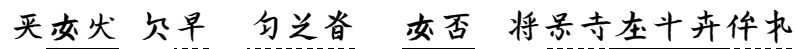
大福哥 娘子“國舅”之 (人名) 將“軍於 嫁第三

Dafuge lady royal uncle of (name) General to marry the 2nd

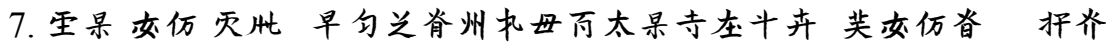
吅夫人拢裡? 國舅 太師於 嫁 $^{-1}$ (人名) 夫人之敌 口's Madam Bali? royal uncle Taishi to marry (name) Madam of late

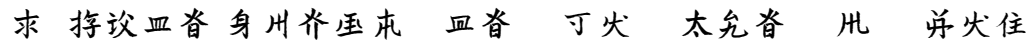
六部之武鄰 six Tribes Telin Khaan House of Chen'ge Taiwei of daughter Ge of

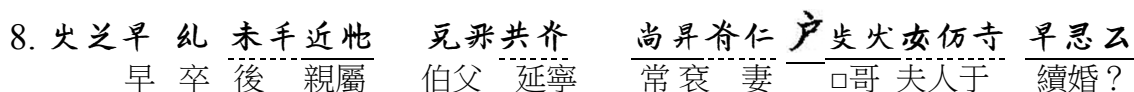

Young die after relatives uncle Yanning Changgun wife age madam to remarry?

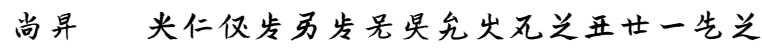

常憝初祇候?

Changgun early Zhihou?
事

matter
歲二十一

age 21 


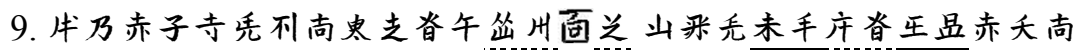

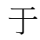

at
號 封

title confer year after Left Yuan

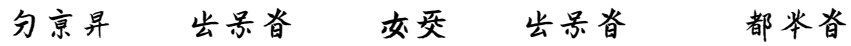 \\ 京之統軍之 副使統軍之都監之}

Jing of command army of FuShi command army of inspector

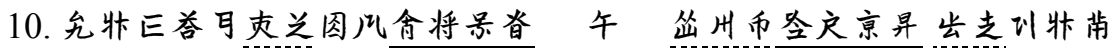
事知 大將軍之 號封年京之同知

Matter manage great General of title confer Zhong Jing of vice governor

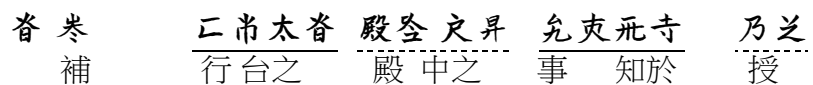

supplement Hangtai of Dianzhong of matter manage to confer

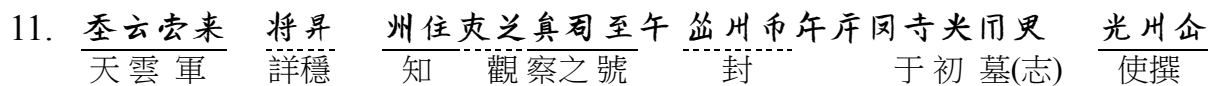
Tianyun army Xianwen manage inspector's title confer at early epitaph let compile

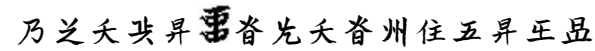

$\begin{array}{ccc}\text { 授 } & \text { 度使之 } & \text { 五 } \\ \text { confer } & \text { Dushi of } & \text { Five Yuan }\end{array}$

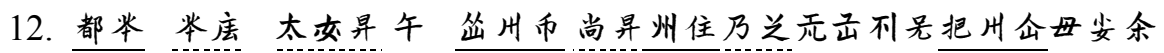
都監檢校太傅之號封常衰授 Dujian Jianjiao Taifu of title confer Changgun confer inherit

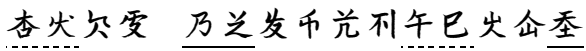
國哥娘子授諸號 Guoge lady confer titles

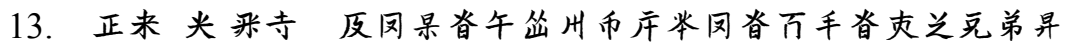
清寧 元年于諸刺史之號 ${ }^{\text {封 }}$

Qingning 1st year at Cishi's title confer manage brothers of

都举苗州住杂兼杲沓午枀州币克弟开都

$\begin{array}{lll}\text { 都監之 } & \text { 禦史之號 } & \text { 兄第之都 } \\ \text { Dujian's } & \text { censor's title brother of Du }\end{array}$

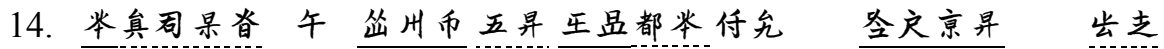
監觀察使之號封五 院都監事京京之 同知

Jian Inspector's title confer Five Yuan Dujian matter Central Capital's vice governor

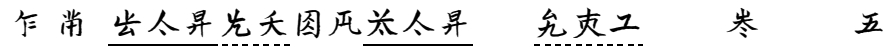
左? 同州之度使鄜州之剚知

left? Tongzhou of Dushi Fuzhou of matter manage supplement five

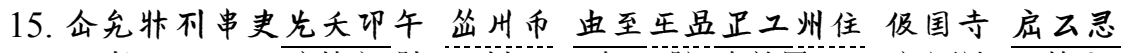

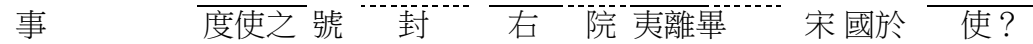

Matter Dushi's title confer Right Yuan Yilibi Song State at Shi?

计特允特不实卫歨左芥乍

事夷離雨於越之応

matter Yilibi Yuyue of Left 


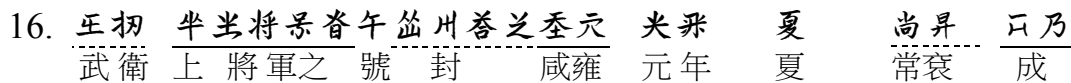
Wuwei Top General's title confer Xianyong 1st year summer Changgun became

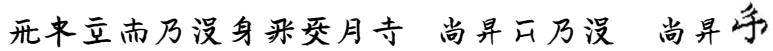

該年九月於敞衰成常衰

that year Sep. at Changgun became Changgun

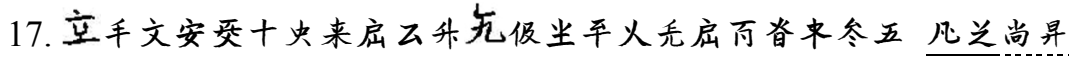

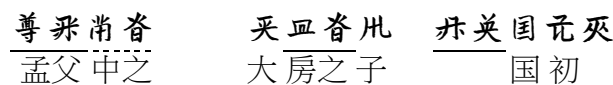

the eldest uncle's the eldest house's son State early

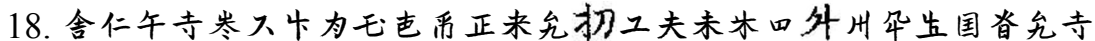
人號於補 清事 man title to supplement clear matter

國之事於

state of matter at

王可之典及云态付没克弟昇无

甲兄弟之

Jia brothers

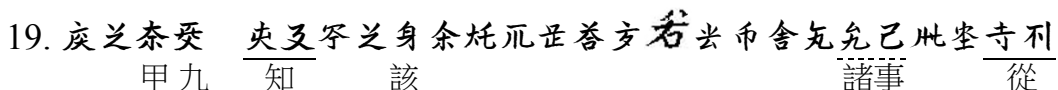

Jia nine manage that

matters from

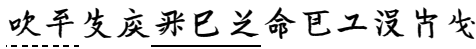

越 諸年

over Years

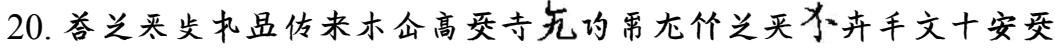

於

at

$\begin{array}{ccc}\text { 大 } & \text { 九 } \\ \text { large } & \text { ten nine }\end{array}$

㟔南乃企光不扔掘不瓦

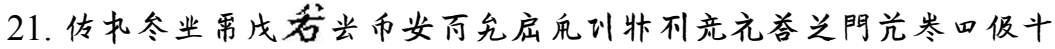

七十

seventy
事

matter
印

seal
補曰

supplement said

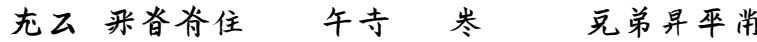

父之母之號於補兄弟之

father's mother's title to supplement brothers

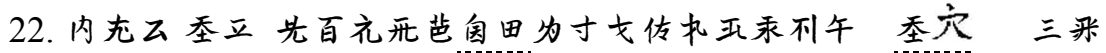

天 百䑚睹”

Heaven hundred Hudu
號 咸雍 三年

title Xianyong 3rd year

十月十三日寺卫捉未沓岑灹母兄并可关荒

十月十三 百於

Oct. 13th date on ill died 


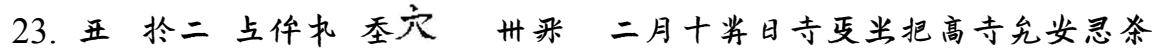
歲 六十二 第二咸䔨 四年二月十七日於 age sixty two the 2nd Xianyong 4th year Feb. 17th date on 事甲 工出位托交寻夾仁左开国寺力开旮寻 卫出位灹交寻夾仁左畀国寺施

now man's state to

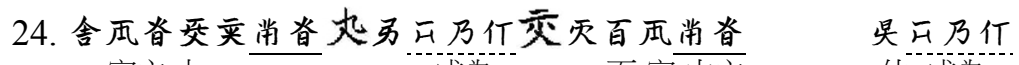
官之九 成為百官中之 仲成為

Officer nine became hundred officers of second became

夷州写早正你

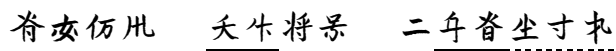
manage rest in peace wife madam son Shi $\square$ General two

epitaph

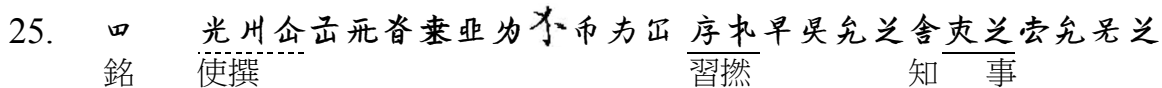
Epigraph let compile Xi'nian matter Jia

尖㳊界爽来長云进局而灷日

$\begin{array}{ll}\text { 雲 } & \text { 諸日? } \\ \text { cloud } & \text { days }\end{array}$

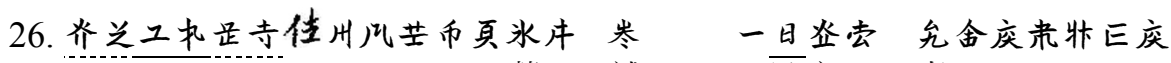
墓補一夜 事 tomb supplement one day night matter
祭捚日 the 3 rd day
任兰月寺
峦处南
事第二月於
甲王
matter the 2nd month in Jia Ren

27. 乃没文传州余至上正巨余夹兄抏弃不灭州并仁左仅

$\begin{array}{ll}\text { 大 } & \text { 祗候? } \\ \text { great } & \text { Zhihou? }\end{array}$

真答之界因未来不高光克至无灭州币

Guanzhong's $\begin{array}{cc}\text { 兄 } & \text { 三十 } \\ \text { G } & \text { elder brother }\end{array}$

28. 韭有身之川尘火是余关身寺尘寸抽四光云

$\begin{array}{cc}\text { 墓 } & \text { 志銘撰 } \\ \text { epitaph } & \text { compile }\end{array}$

四佮

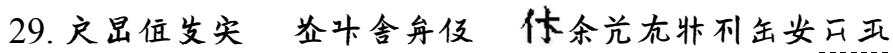

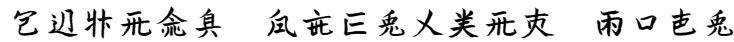

$$
\text { became }
$$

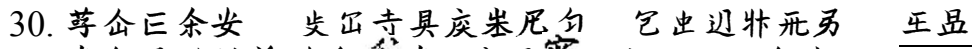

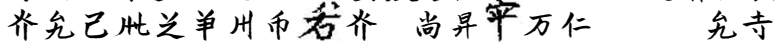

$\begin{array}{ll}\text { 諸事 } & \text { 常衰 萬人 } \\ \text { matters } & \text { Changgun ten thousands matter at }\end{array}$




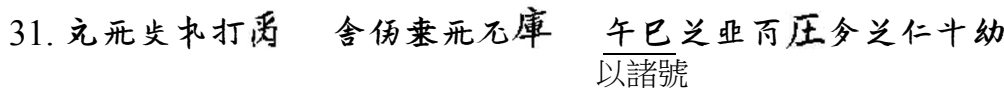
by titles

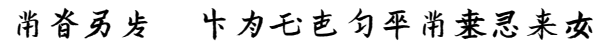

中

of

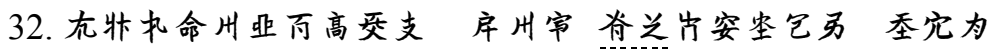

天道
rule

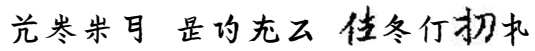

補

supplement

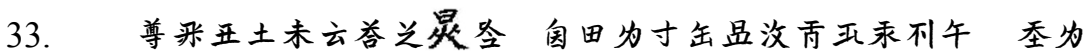

$\begin{array}{llc}\text { 孟父歲 } & \text { 䑚睹 } & \text { 號 天 } \\ \text { eldest uncle age } & \text { Hudu } & \text { title Heaven }\end{array}$

寸文传关百元开芭条工出岑几

百

hundred

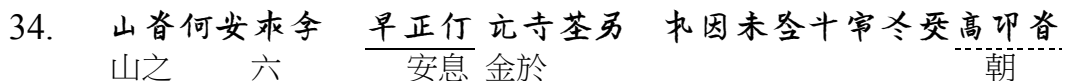

mountain's six rest in peace Jin at

morning

守优 怕州余是昊来出专䀆苗露

dew night of

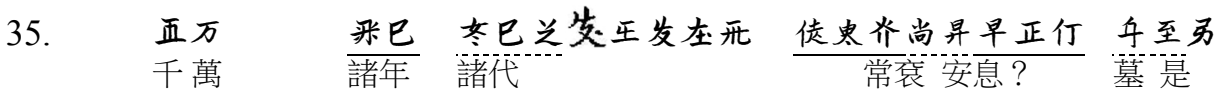
thousand ten thousand years generations Changgun rest in peace tomb be

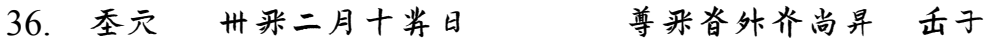
咸雍四年二月十七日孟父之(人名) - 常衰

Xianyong the 4th year Feb. 17th date the eldest uncle of (name) Changgun

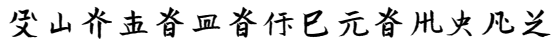
夷離堇 房之
子 書丹
Yilijin House's
son write in red ink 


\section{APPENDIX III}

\section{Pictures of the Rubbing of the Epitaph of Changgun Yelï Zhun of Great Liao in Khitan Large Script ${ }^{4}$}

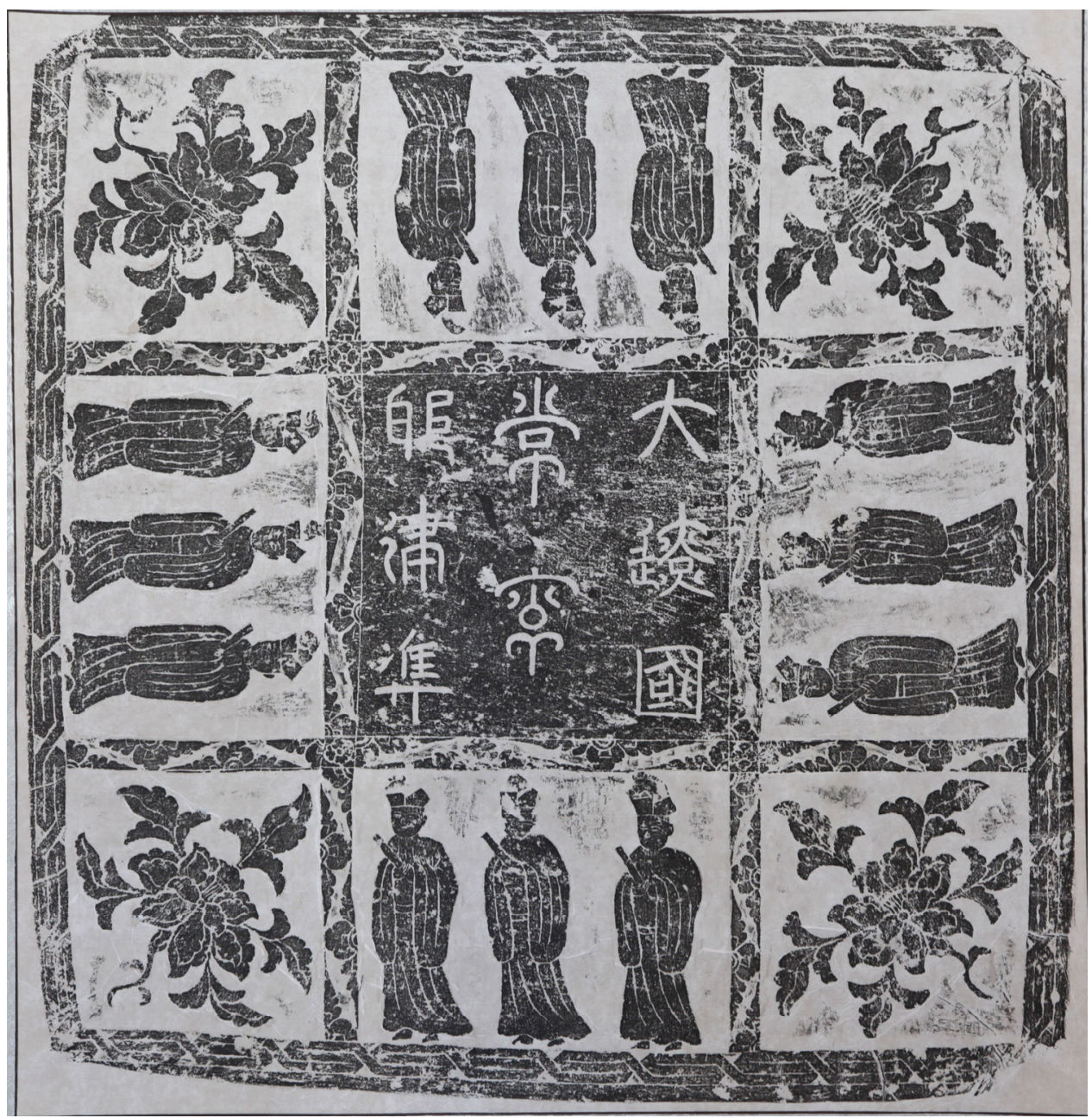

Rubbing of the Cover Stone of the Epitaph of Changgun Yelü Zhun of Great Liao in Khitan Large Script

${ }^{4}$ The pictures of the rubbing have been provided by Shao Guotian, the former curator of the Aohan Banner Museum and Yang Xiaoming, curator of the Xinzhou Museum. We express our heartfelt thanks to them. 


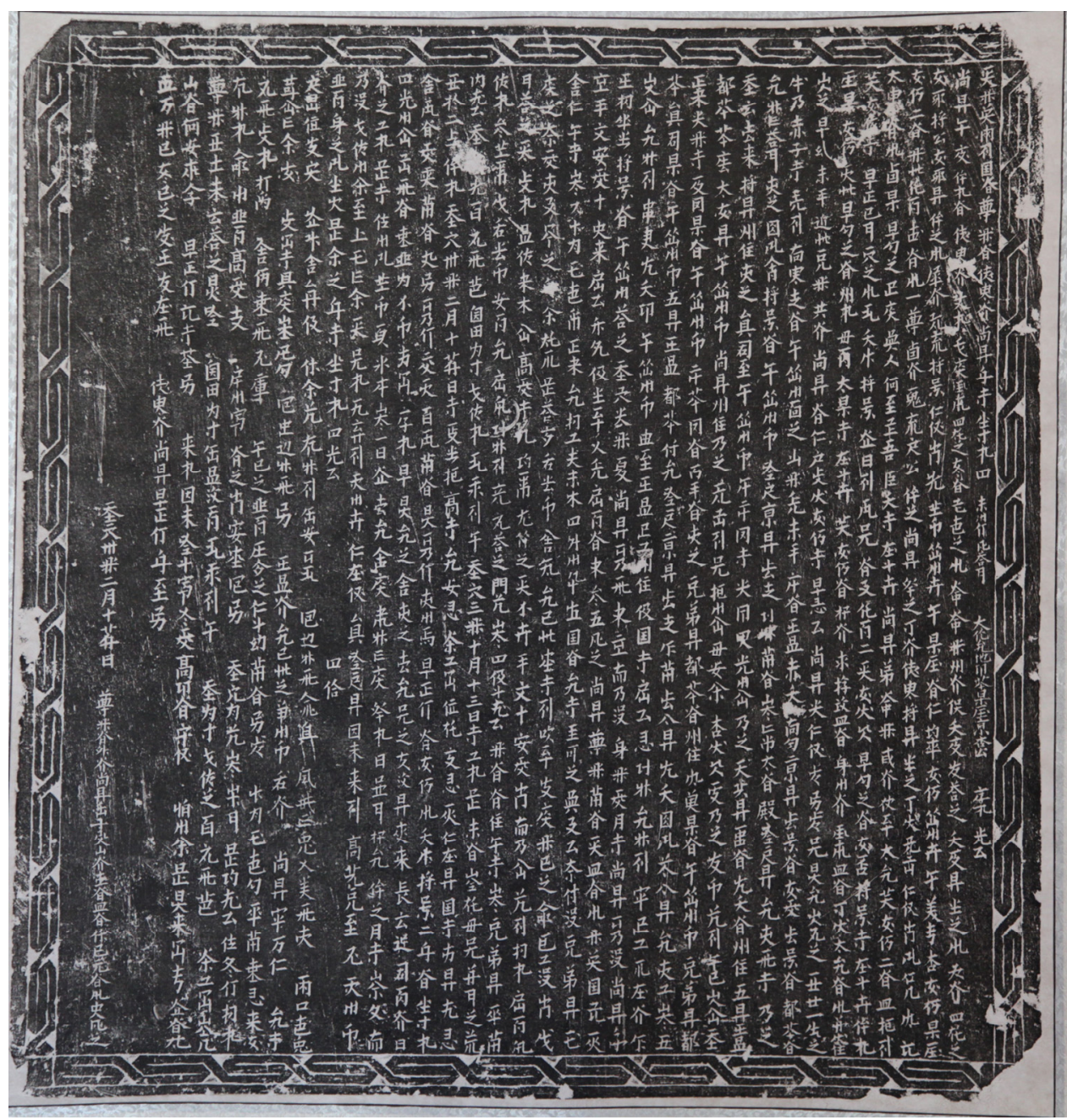

Rubbing of the Base Stone of the Epitaph of Changgun Yelü Zhun of Great Liao in Khitan Large Script 